\title{
Enhanced Antimicrobial, Cytotoxicity, Larvicidal, and Repellence Activities of Brown Algae, Cystoseira crinita-Mediated Green Synthesis of Magnesium Oxide Nanoparticles
}

OPEN ACCESS

Edited by:

Filippo Rossi,

Politecnico di Milano, Italy

Reviewed by:

Vineet Kumar

Lovely Professional University, India

Gharieb El-Sayyad,

Egyptian Atomic Energy Authority,

Egypt

*Correspondence: Amr Fouda

amr_fh83@azhar.edu.eg

Specialty section: This article was submitted to

Nanobiotechnology,

a section of the journal

Frontiers in Bioengineering and

Biotechnology

Received: 06 January 2022 Accepted: 04 February 2022 Published: 28 February 2022

Citation:

Fouda A, Eid AM, Abdel-Rahman MA,

EL-Belely EF, Awad MA Hassan SE-D AL-Faifi ZE and

Hamza MF (2022) Enhanced Antimicrobial, Cytotoxicity, Larvicidal, and Repellence Activities of Brown Algae, Cystoseira crinita-Mediated Green Synthesis of Magnesium Oxide Nanoparticles.

Front. Bioeng. Biotechnol. 10:849921. doi: 10.3389/fbioe.2022.849921

\begin{abstract}
Amr Fouda ${ }^{1 *}$, Ahmed M. Eid ${ }^{1}$, Mohamed Ali Abdel-Rahman ${ }^{1}$, Ehab F. EL-Belely ${ }^{1}$, Mohamed A. Awad ${ }^{2}$, Saad El-Din Hassan ${ }^{1}$, Zarraq E. AL-Faifi ${ }^{3}$ and Mohammed F. Hamza ${ }^{4,5}$

${ }^{1}$ Botany and Microbiology Department, Faculty of Science, Al-Azhar University, Cairo, Egypt, ${ }^{2}$ Department of Zoology and Entomology, Faculty of Science, Al-Azhar University, Cairo, Egypt, ${ }^{3}$ Center for Environment Research and Studies, Jazan University, Jazan, Saudi Arabia, ${ }^{4}$ School of Nuclear Science and Technology, University of South China, Heng Yang, China, ${ }^{5}$ Nuclear Materials Authority, Cairo, Egypt
\end{abstract}

Herein, the metabolites secreted by brown algae, Cystoseira crinita, were used as biocatalyst for green synthesis of magnesium oxide nanoparticles (MgO-NPs). The fabricated MgO-NPs were characterized using UV-vis spectroscopy, Fourier transforms infrared spectroscopy (FT-IR), Transmission Electron Microscopy (TEM), Scanning Electron Microscopy linked with energy-dispersive X-ray (SEM-EDX), X-ray diffraction (XRD), and X-ray photoelectron spectroscopy (XPS). Data showed successful formation of crystallographic and spherical MgO-NPs with sizes of 3-18 nm at a maximum surface plasmon resonance of $320 \mathrm{~nm}$. Moreover, EDX analysis confirms the presence of $\mathrm{Mg}$ and $\mathrm{O}$ in the sample with weight percentages of $54.1 \%$ and $20.6 \%$, respectively. Phyco-fabricated MgO-NPs showed promising activities against Grampositive bacteria, Gram-negative bacteria, and Candida albicans with MIC values ranging between 12.5 and $50 \mu \mathrm{g} \mathrm{mL}^{-1}$. The $\mathrm{IC}_{50}$ value of MgO-NPs against cancer cell lines (Caco-2) was $113.4 \mathrm{\mu g} \mathrm{mL}^{-1}$, whereas it was $141.2 \mathrm{\mu g} \mathrm{mL}^{-1}$ for normal cell lines (Vero cell). Interestingly, the green synthesized MgO-NPs exhibited significant larvicidal and pupicidal activity against Musca domestica. At $10 \mu \mathrm{g} \mathrm{mL}^{-1} \mathrm{MgO}-\mathrm{NPs}$, the highest mortality percentages were 99.0\%, 95.0\%, 92.2\%, and 81.0\% for I, II, III instars' larvae, and pupa of M. domestica, respectively, with $\mathrm{LC}_{50}$ values $\left(3.08,3.49\right.$, and $4.46 \mu \mathrm{g} \mathrm{mL}^{-1}$ ), and $\mathrm{LC}_{90}$ values (7.46, 8.89, and $10.43 \mu \mathrm{g} \mathrm{mL}^{-1}$ ), respectively. Also, MgO-NPs showed repellence activity for adults of $M$. domestica at $10 \mu \mathrm{g} \mathrm{mL}^{-1}$ with $63.0 \%, 77.9 \%, 84.9 \%$, and $96.8 \%$ after $12,24,48$, and $72 \mathrm{~h}$, respectively.

Keywords: Brown algae, Cystoseira crinita, green synthesis, MgO-NPs, antimicrobial, in-vitro cytotoxicity, larvicidal, repellence activity 


\section{INTRODUCTION}

Nanomaterials are materials with at least one dimension and an average size of 1-100 nm with an extraordinary surface area. Its fabrication conditions, shape, and size can be precisely controlled to exhibit certain mechanical, electrical, magnetic, and optical catalytic properties, which distinguish them from their bulk material counterparts (Baig et al., 2021; Shaheen et al., 2021). Magnesium oxide nanoparticles (MgO-NPs) are present in diverse morphological frameworks such as needles, rods, platelets, cubes, flowers, spheres, and stars that qualify them to produce novel nanomaterials (Cao et al., 2020). Currently, green synthesis methods for nanoparticles production are used as alternatives to physicochemical methods. Such methods could produce $\mathrm{MgO}-\mathrm{NPs}$ in an effective, safe, and environmentally friendly manner; in addition, the produced particles are highly stable (Fouda et al., 2021d). Besides that, magnesium is one of the important elements required for plant growth and photosynthesis process. Moreover, the FDA has approved MgO-NPs as a safe and effective antibacterial alternative (Kumar et al., 2020).

Recently, algal biomass, whether dead (dried) or alive, has attracted increasing attention as an environmentally friendly cell factory for the rapid and effective green synthesis of nanoparticles (Uzair et al., 2020; El-Belely et al., 2021). Algae have many unique properties such as rapid growth rate, huge biomass productivity, and capacity for accumulation and reduction of mineral ions. Microalgae and macroalgae can grow without the aid of fertilizers or chemicals. Unlike many biomasses, algae are harvested several times a year (Jacob et al., 2021). It is convenient to utilize algae as nano-factory in a simple water medium at ambient pressure and temperature at natural $\mathrm{pH}$ (Mukherjee et al., 2021). Byproducts of algal metabolism can produce metallic, bimetallic, or metal oxide nanoparticles by reducing, capping, and stabilizing metal precursors (Chaudhary et al., 2020).

Cystoseira crinita Duby is a marine macroalga that belongs to the class of Phaeophyceae (Brown Algae). Brown macroalgae are characterized by powerful biomass that produces various biologically active substances that can act as an effective reducing and stabilizing agent during nanoparticles biosynthesis. Thus, macroalgae-mediated biosynthesis of nanoparticles has become an attractive approach due to the abundance of these biologically active marine resources (Kim and Chojnacka, 2015). Recently, González-Ballesteros and coauthors reported the biogenic synthesis of gold nanoparticles by the marine macroalgae Cystoseira baccata (GonzálezBallesteros et al., 2017). The extract of C. crinita has been reported to have antibacterial, antioxidant, antiviral and cytotoxic, anti-inflammatory, and antiproliferative activities (Bruno De Sousa et al., 2017). However, to the best of our knowledge, there is no report on the green synthesis of $\mathrm{MgO}$ NPs by C. crinita.

The biosynthesize of MgO-NPs was previously reported using fungal strains that manifested potent antimicrobial properties against the selected pathogens, Candida albicans, Bacillus subtilis, Staphylococcus aureus, Escherichia coli, and Pseudomonas aeruginosa, in addition to their catalytic activity for reducing the physicochemical properties and chromium ion content of tanning effluents, along with their adult and larvicidal repellence capacity against Culex pipiens (Hassan et al., 2021; Saied et al., 2021). Furthermore, the Phyto-synthesized MgO-NPs displayed remarkable antimicrobial properties and their toxicological profile revealed powerful toxicity against the breast cancer cell lines (MCF-7), as well as the boosted photocatalytic degradation of MgO-NPs for methylene blue (Amina et al., 2020).

Considering the phyco-nanotechnology, the current study was designed for single-step biosynthesis of magnesium oxide nanoparticles using the aqueous extract of the marine brown macroalgae Cystoseira crinita. The characterization of the biofabricated nanoparticles was fulfilled by UV-Vis spectroscopy, XPS, TEM, XRD, SEM-EDX, and FT-IR analyses. The biomedical performance of the MgO-NPs comprising antimicrobial, in-vitro cytotoxicity, larvicidal, and repellency efficiency was evaluated.

\section{MATERIALS AND METHODS}

\section{Materials Used}

All chemicals used are analytical grades obtained from Sigma Aldrich, Cairo, Egypt. Magnesium nitrate hexahydrate $\left[\mathrm{Mg}\left(\mathrm{NO}_{3}\right)_{2} \cdot 6 \mathrm{H}_{2} \mathrm{O}\right]$ was used as a precursor for $\mathrm{MgO}-\mathrm{NPs}$ synthesis. The antimicrobial activity was conducted using Muller Hinton agar media (ready-prepared-Oxoid), whereas the cell lines used to investigate the In-vitro cytotoxicity were obtained from the Holding Company for Biological Products and Vaccines (VACSERA), Dokki, Giza, Egypt. All the reactions in the current study were conducted using distilled water (dis. $\mathrm{H}_{2} \mathrm{O}$ ).

\section{Macroalgae Biomass Collection}

Biomass of the brown algae $C$. crinita was collected from the Western Red Sea coast of Egypt in Hurghada City $\left(27^{\circ} 17^{\prime} 02.5^{\prime \prime}\right.$ $\left.\mathrm{N}, 33^{\circ} 46^{\prime} 21.0^{\prime \prime} \mathrm{E}\right)$.

\section{Macroalgae Aqueous Extract Preparation and Biosynthesis of MgO-NPs}

The collected biomass of $C$. crinita was washed several times with tap water to remove seawater salts followed by washing with double-distilled water to remove any attached debris and sediments. The epiphytes were removed manually. The washed samples were oven-dried at $70^{\circ} \mathrm{C}$ for $24 \mathrm{~h}$, followed by grinding into a fine powder using an electric blender. Approximately $10 \mathrm{~g}$ of C. crinita powder was mixed with $100 \mathrm{ml}$ dis $\mathrm{H}_{2} \mathrm{O}$, shaken well, and heated at $60^{\circ} \mathrm{C}$ using a magnetic stirrer for $120 \mathrm{~min}$. After that, the mixture was centrifuged for $10 \mathrm{~min}$ at $1500 \mathrm{rpm}$, and the supernatant was collected and used as reducing and stabilizing for $\mathrm{MgO}-\mathrm{NPs}$ as follows: $51.3 \mathrm{mg}$ of metal oxide precursor $\left[\mathrm{Mg}\left(\mathrm{NO}_{3}\right)_{2} \cdot 6 \mathrm{H}_{2} \mathrm{O}\right]$ was dissolved in $10 \mathrm{ml}$ dis. $\mathrm{H}_{2} \mathrm{O}$ and added to $90 \mathrm{ml}$ of obtained algal aqueous extract to get a final concentration of $2 \mathrm{mM}$ (Figure 1). After $24 \mathrm{~h}$ of incubation, the change of color from pale yellow to yellowish-brown indicates the formation of $\mathrm{MgO}-\mathrm{NPs}$ (Pugazhendhi et al., 2019). Finally, the resultant NPs were calcinated at $400^{\circ} \mathrm{C}$ for $4 \mathrm{~h}$. 


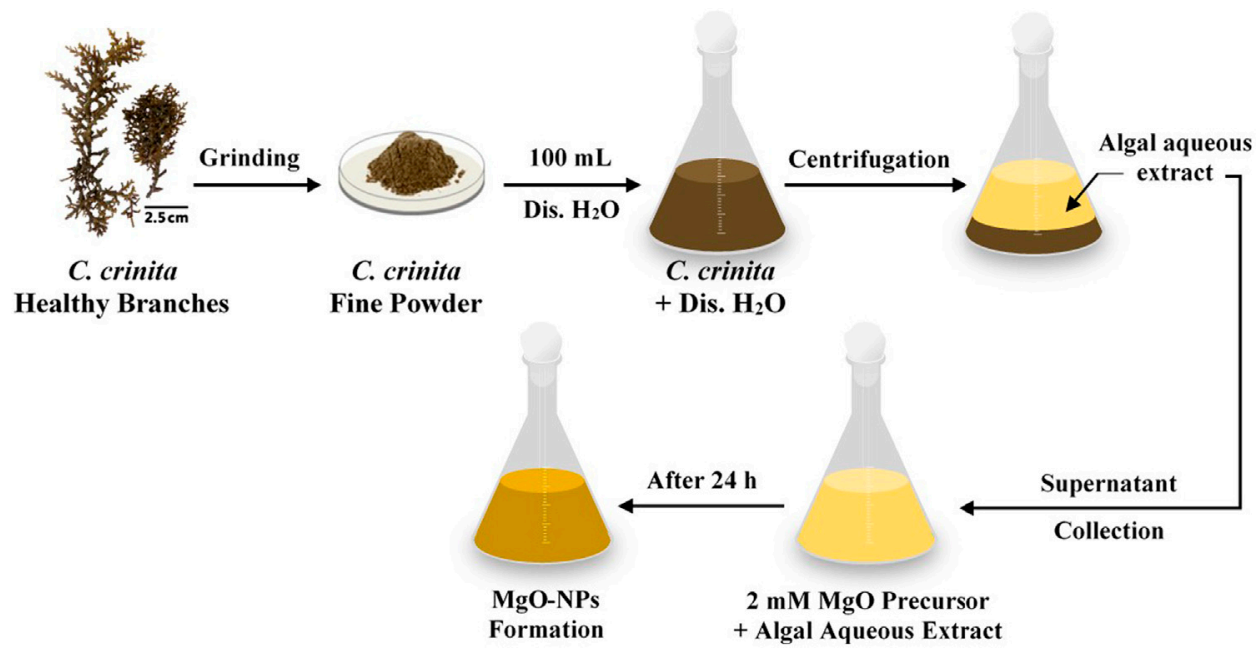

FIGURE 1 | A flowchart shows the biosynthesis of MgO-NPs by the brown algae Cystoseira crinita.

\section{Characterization of Synthesized MgO-NPs}

The maximum surface plasmon resonance (SPR) of biosynthesized $\mathrm{MgO}-\mathrm{NPs}$ was detected through monitoring the absorbance spectra using a UV-Vis spectrophotometer (Jenway 6305, Staffordshire, United Kingdom) in the range of $200-800 \mathrm{~nm}$. The role of functional groups present in the aqueous extract of $C$. crinita in the reduction and stabilizing processes was investigated by Fourier transform infrared (FT-IR) spectroscopy (Agilent system Cary 660 FT-IR model). The NPs sample was mixed with $\mathrm{KBr}$ and pressured to form a disk that was scanned in the range of $400-4000 \mathrm{~cm}^{-1}$ (Badawy et al., 2021). The shapes of biosynthesized MgO-NPs and their sizes are investigated using Transmission Electron Microscopy (TEM) (JEOL 1010, Japan, acceleration voltage of $120 \mathrm{kV}, \mathrm{X} 40000$ ). A drop of MgO-NPs colloidal solution was added to the TEM grid and the solution excess was removed by contacting the gride to blotting paper. The loaded gride was undergone vacuum desiccation for $24 \mathrm{~h}$ before being placed on the TEM holder (Soliman et al., 2021). The elemental contents in the MgO-NPs sample were analyzed using Scanning Electron Microscopy linked with energy-dispersive X-ray (SEM-EDX) (JEOL, JSM6360LA, Japan) (Shaheen and Fouda, 2018).

The X-ray diffraction (XRD) analysis was conducted by X'Pert PRO at a $2 \theta$ degree of $0^{\circ}-80^{\circ}$ (Philips, Eindhoven, Netherlands). The operation conditions were voltage at $40 \mathrm{kV}$, current at $30 \mathrm{~mA}$, and the $\mathrm{x}$-ray source was $\mathrm{Cu} \mathrm{Ka}$ radiation. Based on XRD analysis, the Debye-Scherrer equation was used to measure the particle size (Gu et al., 2018) as follows:

$$
D=0.9 \times 0.154 / \beta \operatorname{Cos} \theta
$$

where D is average particle size, 0.9 is the Scherrer's constant, 0.154 is the wavelength $(\mathrm{nm})$ of X-ray radiation, $\beta$ is the half of maximum intensity, and $\theta$ is the Bragg's angle.

The X-ray photoelectron spectroscopy (XPS) analysis was accomplished by ESCALAB $250 \mathrm{XI}^{+}$instrument (Thermo
Fischer Scientific, Inc., Waltham, MA, USA) connected with monochromatic X-ray $\mathrm{Al} \mathrm{Ka}$ radiation $(1,486.6 \mathrm{eV})$. The analysis was conducted under the following conditions: the size of the spot was $500 \mu \mathrm{m}$, the samples were prepared under a pressure adjusted at $10^{-8} \mathrm{mbar}$, the energy was calibrated with Ag3d $\mathrm{d}_{5 / 2}$ signal $(\triangle \mathrm{BE}: 0.45 \mathrm{eV})$ and $\mathrm{C} 1 \mathrm{~s}$ signal $(\triangle \mathrm{BE}: 0.82 \mathrm{eV})$, and the full and narrow-spectrum pass energies were 50 and $20 \mathrm{eV}$, respectively (Hamza et al., 2021a).

\section{Biological Activities \\ Antimicrobial Activity}

The activity of phyco-synthesized MgO-NPs against pathogenic Gram-positive bacteria (Staphylococcus aureus ATCC6538, Bacillus subtilis ATCC6633), Gram-negative bacteria (Pseudomonas aeruginosa ATCC9022, Escherichia coli ATCC8739), and unicellular fungi (Candida albicans ATCC10231) was investigated by the agar well diffusion method. Briefly, the bacterial strains and C. albicans were inoculated on nutrient broth media and yeast extract peptone dextrose (YEPD), respectively, and incubated at $35.0 \pm 2^{\circ} \mathrm{C}$ for $24 \mathrm{~h}$ (Fouda et al., 2021b). At the end of the incubation period, $50 \mu \mathrm{L}$ of each microbial strain (adjusted O.D. at 1.0) were seeded onto Muller Hinton agar media, shaken well, and poured into Petri dishes under sterilized conditions. After the solidification, wells $(0.7 \mathrm{~mm})$ were made in seeded plates before being filled with $100 \mu \mathrm{L}$ of stock MgO-NPs solution $\left(200 \mu \mathrm{g} \mathrm{mL} \mathrm{m}^{-1}\right)$. The loaded Muller Hinton plates are kept in the refrigerator for one hour before being incubated at $35.0 \pm 2^{\circ} \mathrm{C}$ for $24 \mathrm{~h}$ (Fouda et al., 2021a). At the end of the incubation period, the results were recorded as a diameter of the zone of inhibition $(\mathrm{mm})$ that appeared around each well. The activity of different $\mathrm{MgO}-\mathrm{NPs}$ concentrations (100, 50,25 , and $12.5 \mu \mathrm{g} \mathrm{mL}^{-1}$ ) was also investigated in the same manner to detect the minimum inhibitory concentration (MIC) value for each test organism. The experiment was achieved in triplicates. 


\section{In-vitro Cytotoxicity}

Cell culture used: Two cell lines represented by Vero cells (kidney of African green monkey) as normal cells and Caco-2 cells (colon carcinoma cell) as cancerous cells.

MTT assay method. The in-vitro cytotoxic efficacy of phycosynthesized MgO-NPs was studied by the cell viability MTT [3(4,5-dimethylthiazol-2-yl)-2,5-diphenyl tetrazolium bromide] assay method. Briefly, the selected cell lines were grown separately in a 96-well microtiter plate at a concentration of $1 \times 10^{5} \mathrm{cell} /$ well. The inoculated plates were treated by the doublefold MgO-NPs concentration (500, 250, 125, 62.5, 31.25, 15.6, and $7.8 \mu \mathrm{g} \mathrm{mL} L^{-1}$ ) and incubated at $37^{\circ} \mathrm{C}$ for $48 \mathrm{~h}$. At the end of the incubation period, MTT reagent $\left(5 \mathrm{mg} \mathrm{mL}^{-1}\right.$ in phosphate buffer) was added to each well and incubated under $5 \% \mathrm{CO}_{2}$ at $37^{\circ} \mathrm{C}$ for 1-5 h. After that, the purple formazan crystal (MTT metabolic product) was formed which was dissolved by the addition of $10 \%$ DMSO. The plates were subjected to agitation for $30 \mathrm{~min}$ in dark conditions and followed by the measure of the formed color intensity at $560 \mathrm{~nm}$ by an enzyme-linked immunosorbent assay (ELISA) plate reader (Lashin et al., 2021). The cell viability percentages were measured according to the following equation:

Cell viability percentages $(\%)=\frac{\text { Absorbance of treated sample }}{\text { Absorbance of control }} \times 100$

\section{Mosquitocidal Bioassay \\ Larvae Rearing}

The laboratory-bred colony of Musca domistica (housefly) was obtained from animal houses, Flies Research Laboratory, Faculty of Science, Al-Azhar University, Cairo, Egypt. Larval and pupae instars were then reared in a plastic cup containing dried Brewer's beans, yeast extract, and milk powder in standard conditions of $28.0 \pm 2.0^{\circ} \mathrm{C}$ (Hogsette, 1992).

\section{Larvicidal and Pupicidal Bioassay}

Larval bioassay was estimated using the dipping method according to Sinthusiri and Soonwera (2010). Five concentrations of MgO-NPs were prepared $(2,4,6,8$, and $10 \mu \mathrm{g} \mathrm{m}^{-1}$ ), 25 third instar larvae were dipped in $10 \mathrm{ml}$ of each concentration of the nano-scaled colloidal $\mathrm{MgO}$ for $30 \mathrm{~s}$ and then transferred to filter paper (in a plastic beaker). Three replicates were prepared for each concentration, while control larvae were dipped in distilled water for $30 \mathrm{~s}$. Larval mortality percentages were recorded after $24 \mathrm{~h}$ of treatment according to the following equation (Fouda et al., 2020):

$$
\text { Mortality percentages }(\%)=\frac{\mathrm{A}-\mathrm{B}}{\mathrm{B}} \times 100
$$

where A is the mortality percentages in treatment and $\mathrm{B}$ is the mortality percentages in control.

\section{Repellent/Attraction Assay}

Twenty newly emerged mixed-sex adults were housed in a cage $(18 \times 24 \times 18$ inches $)$ containing two conical flasks. One of the two flasks contained $1 \% \mathrm{MgO}-\mathrm{NPs}\left(10 \mu \mathrm{g} \mathrm{mL}^{-1}\right)$ in $5 \mathrm{ml}$ of milk, while the other contained $5 \mathrm{ml}$ of milk to be used as a control. A
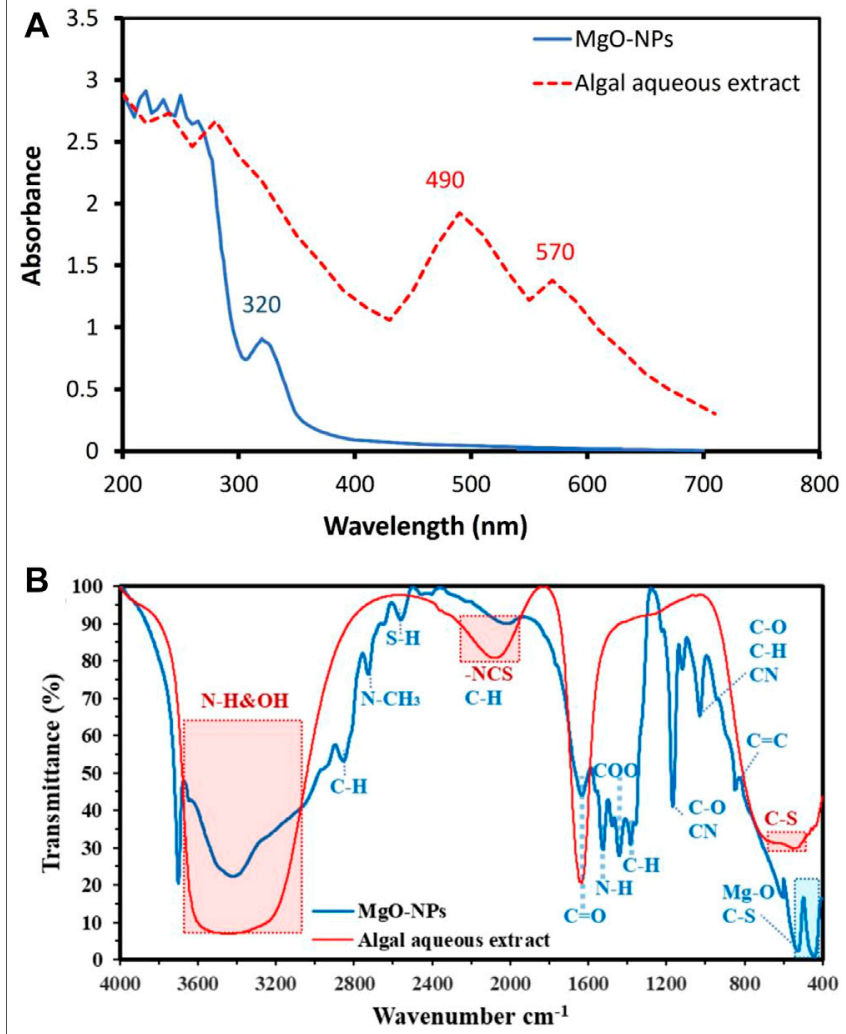

FIGURE 2 | UV-vis spectroscopy (A) and FT-IR (B) for algal aqueous extract and MgO-NPs synthesized by brown algae C. crinita.

funnel (4 inches in diameter) was inserted into each flask to prevent the escape of flies. The total number of flies trapped in these flasks was counted after $24 \mathrm{~h}$. The results were expressed in terms of the attraction/repulsion ratio. The repellence percentage (R, \%) was calculated by the following formula (Campbell, 1983):

$$
\text { Repellence percentages }(\%)=\frac{C-T}{C} \times 100
$$

where $\mathrm{C}$, is the number of flies restricted in the control flask and $\mathrm{T}$, is the number of flies restricted in the treated flask. This experiment was performed with five repetitions.

\section{Statistical Analysis}

All the results presented are the means of three independent replicates. Data were subjected to statistical analysis by a statistical package SPSS v17. The mean difference comparison between the treatments was analyzed by $t$-test or the analysis of variance (ANOVA) and subsequently by Tukey HSD test at $p<0.05$.

\section{RESULTS AND DISCUSSION}

\section{UV-Vis Spectroscopy Analysis}

The first monitor for phyco-synthesis of MgO-NPs was the color change from pale yellow to yellowish-brown due to the mixing of 

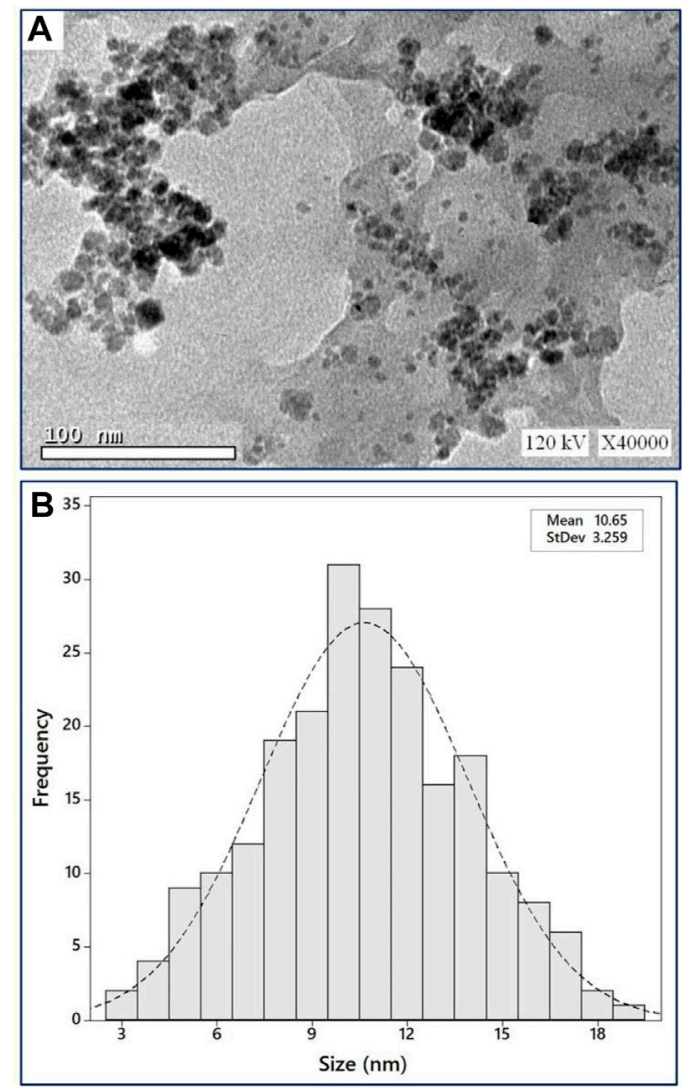

FIGURE 3 | Characterization of green synthesized MgO-NPs by brown algae C. crinita. (A) TEM image showed spherical shape, (B) size distribution of particles based on TEM image.

aqueous extract of $C$. crinita with $\mathrm{Mg}\left(\mathrm{NO}_{3}\right)_{2} \cdot 6 \mathrm{H}_{2} \mathrm{O}$. This change was investigated by UV-vis spectroscopy to detect the maximum surface plasmon resonance (SPR), which mainly depends on the size, distribution, and shape of phyco-synthesized MgO-NPs in the colloidal solution (Fedlheim and Foss, 2001). In this reaction, the UV radiations react with the metals in the tested solution that support the transition of electrons from low to a higher energy state, then the SPR is obtained which gives a prediction about the shape and size of NPs in the range of (2-100 nm) (Poinern, 2014). In this study, the maximum SPR was appeared at $320 \mathrm{~nm}$, whereas algal aqueous extract has two maximum peaks at 490 and $570 \mathrm{~nm}$ (Figure 2A). The shifting in maximum peak confirmed the successful formation of MgO-NPs by algal metabolites present in the aqueous extract that act as reducing and capping/stabilizing agents. Compatible with the current study, the aqueous extract of brown algae Sargasssum wightii was changed to yellowish-brown after being mixed with $\mathrm{Mg}\left(\mathrm{NO}_{3}\right)_{2}$ as an indication of $\mathrm{MgO}-\mathrm{NPs}$ formation, and the maximum SPR was appeared at $322 \mathrm{~nm}$ (Pugazhendhi et al., 2019). The presence of adsorption peaks at wavelength $200-250 \mathrm{~nm}$ refers to the existence of different bioactive compounds in algal aqueous extract such as alginates and polyphenols that play a critical role in the reduction of $\mathrm{Mg}\left(\mathrm{NO}_{3}\right)_{2} \cdot 6 \mathrm{H}_{2} \mathrm{O}$ to form MgO-NPs (Pugazhendhi et al., 2019).

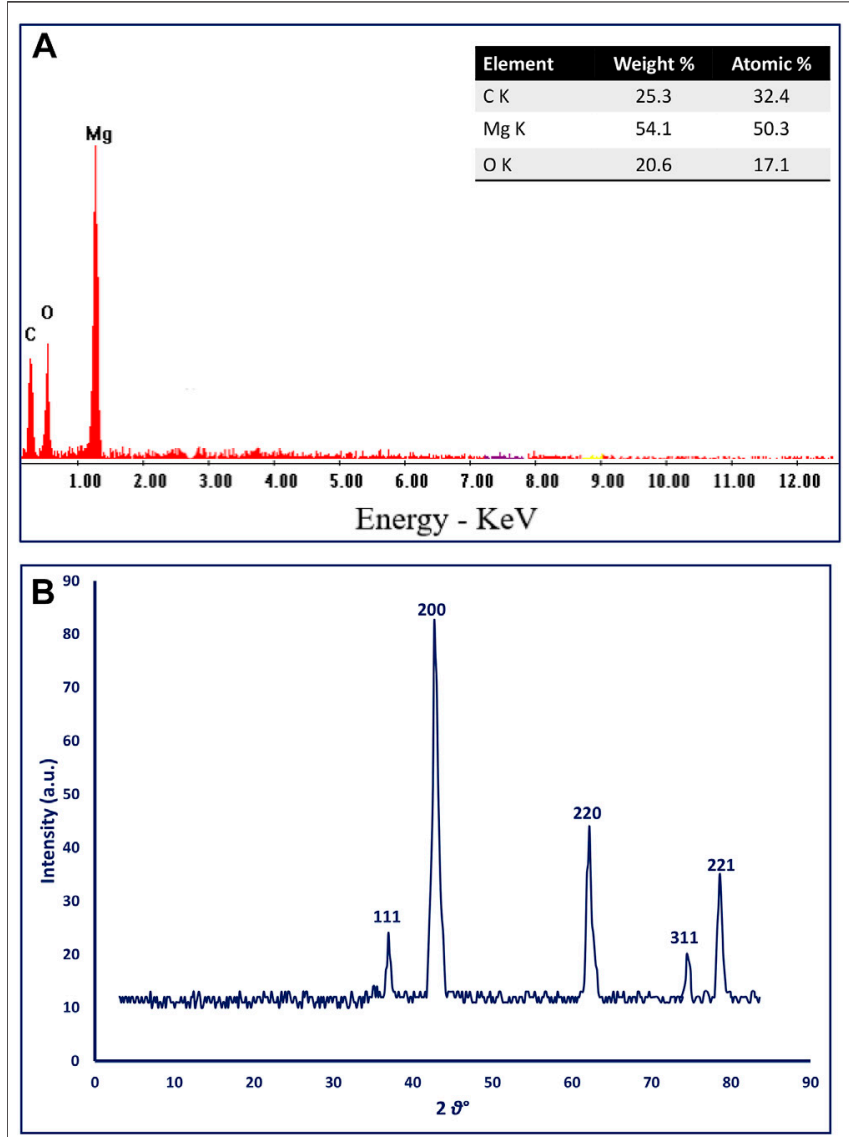

FIGURE 4 | (A) The EDX chart, and (B) XRD analysis of algal-mediated green synthesized MgO-NPs.

The synthesis of NPs in our study is extracellular mode that is more convenient as the produced NPs are easily purified. Several compounds aid as reducing agents. As previously reported, the dominant biomolecules in brown algae are sterols such as cholesterols, fucosterols, sulfated polysaccharides, and various functional groups including glucuroronic acid, muramic acid, alginic acid, and vinyl derivatives that could act as reducing as well as capping agents for the synthesis of NPs (Chaudhary et al., 2020). For synthesis conditions, the $\mathrm{pH}$ of reaction medium is one of the important used experimental parameters in our synthetic method (Fouda et al., 2018). Here, the conducted alkaline condition used for NPs synthesis, as compared with neutral condition, enhances the reducing power of functional groups and prevents the NPs agglomeration (Parial et al., 2012). Besides that, it helps in the NPs capping and stabilization by interacting with the amine groups of surface-bound proteins and their residual amino acids (Namvar et al., 2014). Further experiments for the effect of different $\mathrm{pH}$ values, temperature, time, static conditions, substrate concentration, and stirring to find the optimal reaction conditions and the best physical characteristics of NPs should be investigated for the validation of all experimental conditions. 

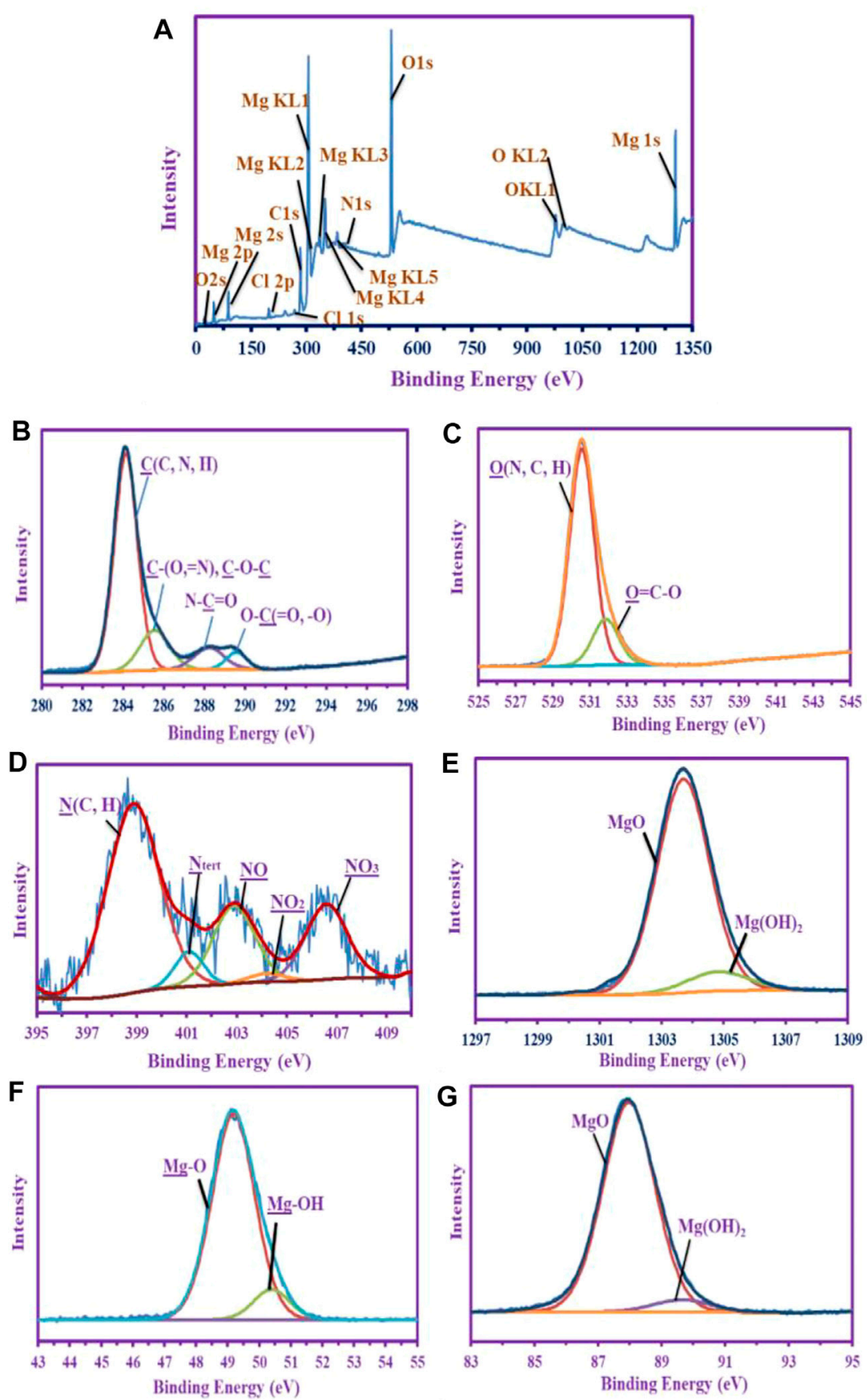

FIGURE 5 |XPS analysis of MgO-NPs synthesized by harnessing metabolites of brown algae C. crinita. (A) Total analysis an overview; (B) denotes the C 1s; (C) denotes the O 1s; (D) denotes the N 1s; (E) denotes the Mg 1s; (F) denotes the Mg 2p; and (G) denotes the Mg 2s.

Fourier Transform Infrared Spectroscopy

The bioactive compounds present in the aqueous extract of brown algae $C$. crinita and their role in the reduction, capping, and stabilizing of MgO-NPs were identified by FT-IR analysis (Figure 2B). FT-IR of the algal aqueous extract confirms the presence of $\mathrm{C}=\mathrm{O}$ from polysaccharide moieties at $1627 \mathrm{~cm}^{-1}$, whereas the broadband at $2075 \mathrm{~cm}^{-1}$ is related to -NCS stretching of fucoidan from biomass that explains the sulfone stretching peak (Hamza et al., 2020a; Hamza et al., 2020b). The strong broadness of bands at 3340 related to $\mathrm{OH}$ and $\mathrm{NH}$ stretching vibration. The appearance of absorption peaks in the range of $450-650 \mathrm{~cm}^{-1}$ refers to the successful formation of $\mathrm{Mg}-\mathrm{O}$ (Ramanujam and Sundrarajan, 2014; Pugazhendhi et al., 2019; Fouda et al., 2021c); this peak overlapped with the C-S band from the biomasses (Hamza et al., 2021b). The weak absorption peak at $840 \mathrm{~cm}^{-1}$ corresponded to bending $\mathrm{C}=\mathrm{C}$ of alkene. The peak at 
$1027 \mathrm{~cm}^{-1}$ related to stretching $\mathrm{C}-\mathrm{O}$ or bending $\mathrm{C}-\mathrm{H}$ or stretching CN of primary amines (Coates, 2006; Hamza et al., 2019), whereas the peak at $1166 \mathrm{~cm}^{-1}$ corresponded to stretching $\mathrm{C}-\mathrm{O}$ of the alcohol and overlapped with stretching $\mathrm{C}-\mathrm{N}$ of tertiary amines (Coates, 2006). The absorption peak at $1395 \mathrm{~cm}^{-1}$ is related to the vibration of $\mathrm{C}-\mathrm{H}$ bending (Ogunyemi et al., 2019), whereas the peak at $1438 \mathrm{~cm}^{-1}$ is corresponded to stretching $\mathrm{C}=\mathrm{O}$ of carboxylic salts and adsorption of $\mathrm{CO}_{2}$ and $\mathrm{CO}_{3}{ }^{2-}$ on the MgO-NPs surface (Coates, 2006; Hamza et al., 2021b). The absorption peak at $1628 \mathrm{~cm}^{-1}$ is related to water adsorption in the sample (Moorthy et al., 2015), whereas the broad peak at $2000 \mathrm{~cm}^{-1}$ is signified to $\mathrm{C}-\mathrm{H}$ bending of aromatic compounds overlapped with -NCS of biomass (Hamza et al., 2020a). The weak absorption peak at $2557 \mathrm{~cm}^{-1}$ is referred to stretching of the $\mathrm{S}-\mathrm{H}$ group of thiol-containing compounds, whereas the peak at 2723 corresponds to $\mathrm{N}-\mathrm{CH}_{3}$ methylamine and stretching $\mathrm{C}-\mathrm{H}$ bond (these data are matched with XPS analysis) (Coates, 2006). The small absorption peak at $2850 \mathrm{~cm}^{-1}$ signifies to stretching vibration bond of $\mathrm{C}-\mathrm{H}$ in $\mathrm{CH}_{2}$ groups' existence in the phyco-chemical compounds (Essien et al., 2020). Finally, the broad and strong peaks that appeared in the range of $3400 \mathrm{~cm}^{-1}$ to $3700 \mathrm{~cm}^{-1}$ corresponded to the $\mathrm{N}-\mathrm{H}$ and $\mathrm{O}-\mathrm{H}$ groups of different amino acids present in the aqueous extract of brown algae (Moorthy et al., 2015; Pugazhendhi et al., 2019). Jena and coworkers reported that the most common functional groups present in the algal aqueous extract and responsible for NPs fabrications are $-\mathrm{NH}_{2}-,-\mathrm{C}=\mathrm{O}-$, and $-\mathrm{SH}$ - groups (Jena et al., 2014). According to the FT-IR analysis, the role of bioactive compounds such as amino acids, polysaccharides, primary and tertiary amines, and others that are present in the aqueous extract of brown algae has been confirmed to act as reducing, capping, and stabilizing of MgO-NPs.

\section{Transmission Electron Microscopy}

The activity of NPs is usually correlated with different characters including shape, size, and distribution (Salem and Fouda, 2021). Therefore, it is important to detect the size and shape of NPs. As shown from the TEM analysis in Figure $\mathbf{3 A}$, the bioactive compounds present in the aqueous extract of macroalgae $C$. crinita have the efficiency to fabricate spherical and welldispersed MgO-NPs with a size range of 3.0-18.0 nm with an average size diameter of $10.65 \pm 3.3 \mathrm{~nm}$ (Figure 3B). As mentioned in the previous studies, the activity of NPs is increased by decreasing their size. For example, the activity of $\mathrm{MgO}-\mathrm{NPs}$ to inhibit the growth of pathogenic Gram-positive Bacillus subtilis was varied according to the sizes used. The inhibition percentages were $75.7 \%, 94.5 \%$, and $96.1 \%$ for size 2145.9, 47.3, and $35.9 \mathrm{~nm}$, respectively (Huang et al., 2005). Moreover, spherical MgO-NPs synthesized through harnessing metabolites of Penicillium chrysogenum exhibited a size range of $7-40 \mathrm{~nm}$ and showed inhibition activity against pathogenic Gram-positive bacteria, Gram-negative bacteria, and unicellular fungi as well against larvae and pupa of malarial vector Anopheles stephensi (Fouda et al., 2021a). The obtained size (3.0-18.0 nm) of MgO-NPs in the current study is expected to have high activity for various biomedical and biotechnological applications.

\section{Energy-Dispersive X-Ray Analysis}

The EDX analysis is used to detect the elemental composition of the biosynthesized MgO-NPs. The EDX chart showed that the phyco-synthesized MgO-NPs are highly pure; it contains $\mathrm{Mg}$ and $\mathrm{O}$ ions which indicates the successful formation of $\mathrm{MgO}$ through harnessing metabolites present in the aqueous extract of brown algae C. crinita (Figure 4A). Also, the existence peak of $\mathrm{Mg}$ and $\mathrm{O}$ at bending energy between 0.5 and $1.5 \mathrm{KeV}$ confirms the successful formation of $\mathrm{MgO}$ (Fouda et al., 2021e). The quantitative analysis revealed that the weight percentages of $\mathrm{Mg}$ and $\mathrm{O}$ ion in the sample were 54.1 and $20.6 \%$, respectively, whereas the atomic percentages were $50.3 \%$ and $17.1 \%$, respectively (Figure 4A). Similarly, the EDX profile of $\mathrm{MgO}-\mathrm{NPs}$ fabricated by the Pterocarpus marsupium aqueous extract showed two peaks at 0.5 and $1.5 \mathrm{KeV}$ for $\mathrm{O}$ and $\mathrm{Mg}$ ions with weight percentages of 69.3 and $30.6 \%$, respectively (Ammulu et al., 2021). The presence of $\mathrm{C}$ indicates the bounding of algal metabolites to the MgO-NPs surface. Compatible with the current study, the presence of carbon in the EDX chart of $\mathrm{MgO}$ NPs was attributed to the attached biomolecules secreted by brown algae Sargasssum wightii to the surface of $\mathrm{MgO}$ (Pugazhendhi et al., 2019).

\section{X-Ray Diffraction Analysis}

The crystallinity of phyco-synthesized MgO-NPs was investigated using the XRD pattern. The data represented in Figure $4 \mathrm{~B}$ showed five intense peaks at $2 \theta$ values of $36.9^{\circ}, 42.6^{\circ}$, $62.2^{\circ}, 74.7^{\circ}$, and $78.8^{\circ}$ which corresponded to (111), (200), (220), (311), and (222), respectively. The obtained peaks confirmed that the phyco-synthesized MgO-NPs were a crystallographic and face-centered cubic structure (FCC) as compared with JCPDS file no.39-7746 (Pugazhendhi et al., 2019). The size of biosynthesized MgO-NPs can be calculated according to the width of the sharp XRD peak (200) located at a $2 \theta$ value of $42.7^{\circ}$ by Debye Scherrer's equation. Data showed that the mean crystal size of phycosynthesized $\mathrm{MgO}-\mathrm{NPs}$ was $21 \mathrm{~nm}$ based on XRD analysis. Similar XRD spectra were recorded for green synthesized MgO-NPs by different biological entities (Sharma et al., 2020; Ammulu et al., 2021; Hassan et al., 2021).

\section{X-Ray Photoelectron Spectroscopy Analysis}

The XPS analysis of MgO-NPs was analyzed and characterized by several identified peaks. Figure 5A depicts the survey analysis spectra of the sample, which has several peaks of the constituents; this appears in $\mathrm{C} 1 \mathrm{~s}, \mathrm{~N}$ 1s, $\mathrm{Cl}$ (1s, 2p), O (1s, KL1, 2s, and KL2), whereas the $\mathrm{Mg}$ was detected at different bending energy (BE) as $1 s, 2 s, 2 p$, and KL1-5 verifying a majority product of this element over the other elements.

Different profiles of deconvolutions and signals were shown in comparing the chemical constituents. The deconvoluted and assignment peaks of the most abundant groups or species are recorded. The $\mathrm{C} 1 s$ shows five splitting internal peaks, which are assigned as $\mathrm{C}(\mathrm{C}, \mathrm{N}, \mathrm{H})$ at $284.09 \mathrm{eV}, \mathrm{C}(=\mathrm{N}, \mathrm{O})$ or $\mathrm{C}-\mathrm{O}-\mathrm{C}$ at $285.51 \mathrm{eV}, \mathrm{N}-\mathrm{C}=\mathrm{O}$ (amide) at $288.18 \mathrm{eV}$, and $\mathrm{O}-\mathrm{C}=\mathrm{O}$ and $\mathrm{O}-\mathrm{C}-\mathrm{O}$ at $289.53 \mathrm{eV}$, respectively (Figure 5B) (Jurado-López et al., 2017; 


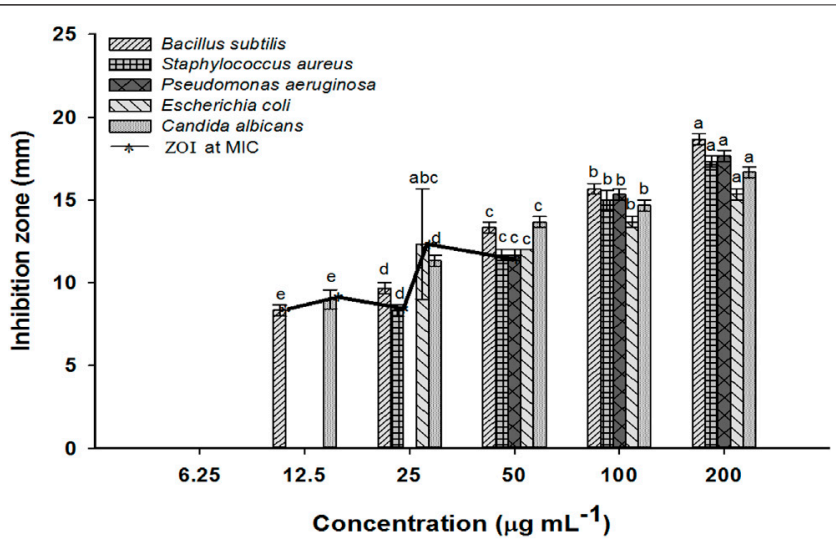

FIGURE 6 | The antimicrobial activity of MgO-NPs at different concentrations against Gram-positive and Gram-negative bacteria, and unicellular fungi and inhibition zones at MIC. Different letters at the same concentration indicate the significant vales $(p \leq 0.05)$.

Hamza et al., 2019; He et al., 2021). Two internal splitting peaks were shown for the $\mathrm{O} 1 \mathrm{~s}$ peak (Figure 5C) which was assigned for $\mathrm{O}(\mathrm{N}, \mathrm{C}, \mathrm{H})$ at $530.52 \mathrm{eV}$, and the other peak for $\mathrm{O}-\mathrm{C}=\mathrm{O}$ at $531.8 \mathrm{eV}$ (Jurado-López et al., 2017; Hamza et al., 2021b; Wei et al., 2021). This proves the chemical composition of the hydrocarbon (i.e., carbohydrate moiety) produced by the brown algae is compatible with the EDX chart.

The $\mathrm{N}$ 1s was splitting into five internal peaks assigned at $398.82 \mathrm{eV}$ for $\mathrm{N}(\mathrm{C}, \mathrm{H})$, and $401.04 \mathrm{eV}$ for $\mathrm{N}_{\text {tert }}$, this is for polysaccharides moieties (Lu et al., 2019; He et al., 2021), whereas the medium of the sorption and the dissolved salt source was appeared by three peaks 402.84, 404.15, and $406.54 \mathrm{eV}$ for $\mathrm{NO}, \mathrm{NO}_{2}$, and $\mathrm{NO}_{3}$, respectively (Figure 5D) (Bartis et al., 2015).

As shown in Figures $\mathbf{5 E - G}$ the $\mathrm{Mg}$ is predominately an oxide over the hydroxide species; this was shown in the Mg1s which split into two peaks at $1303.65 \mathrm{eV}$ with (at\%) 88.83, and the other peak at $1304.77 \mathrm{eV}$ for $\mathrm{Mg}(\mathrm{OH})_{2}$ with $11.7 \%$ (at\%) (Yao et al., 2013). Mg2p shows the same deduction as in the Mg1s, the majority for the $\mathrm{MgO}$ at $49.14 \mathrm{eV}$, (at\%) 88.77 over $\mathrm{Mg}-\mathrm{OH}$ $50.34 \mathrm{eV}$ (at\% 11.23\%) (Dang et al., 2017; Le Febvrier et al., 2017), whereas the $\mathrm{Mg} 2 \mathrm{~s}$ deconvoluted twice at $87.93 \mathrm{eV}$ with $90.76 \%$ (at \%) for $\mathrm{MgO}$ and at $89.6 \mathrm{eV}$ with $9.24 \%$ (at\%) for $\mathrm{Mg}(\mathrm{OH})_{2}$ (Dang et al., 2017). This emphasizes the predominantly abundant $\mathrm{MgO}$ species over $\mathrm{Mg}(\mathrm{OH})_{2}$ species and the majority of $\mathrm{Mg}$ in the yield.

\section{Antimicrobial Activity of MgO-NPs}

The agar well diffusion assay was used to evaluate the microbicidal activities of the phyco-synthesized MgO-NPs. Measurement of inhibition zones developed around agar wells demonstrated the dose-dependent activity of MgO-NPs against selected clinical pathogens (Bacillus subtilis, Staphylococcus aureus, Pseudomonas aeruginosa, Escherichia coli, and the unicellular fungi (Candida albicans) as recently reported (Hassan et al., 2021). The results proved the divergent activity of the nanostructured $\mathrm{MgO}$ against all tested pathogens. The $\mathrm{MgO}-\mathrm{NPs}$ at $50 \mu \mathrm{g} \mathrm{mL} \mathrm{m}^{-1}$ exhibited a wide spectrum activity against all tested microbes. Bacillus subtilis was the most sensitive strain recording $13.3 \pm 0.5 \mathrm{~mm}$ zone of inhibition (ZOI). Doubling the concentration of MgO-NPs $(100 \mu \mathrm{g}$ $\mathrm{mL}^{-1}$ ) improved the antimicrobial activity, and B. subtilis retained the biggest ZOI $(15.6 \pm 0.5 \mathrm{~mm})$, whereas $E$. coli had the smallest $\mathrm{ZOI}(13.6 \pm 0.5 \mathrm{~mm})$. The $\mathrm{MgO}-\mathrm{NPs}$ concentration at $200 \mu \mathrm{g} \mathrm{mL}^{-1}$ showed the maximum effectiveness against all microbes, $B$. subtilis recorded the largest ZOI $(18.6 \pm 0.5 \mathrm{~mm})$, whereas it was $15.3 \pm 0.5 \mathrm{~mm}$ for E. coli. Moreover, S. aureus, $P$. aeuroginosa, and C. albicans recorded $17.3 \pm 0.5,17.6 \pm 0.5$, and $16.6 \pm 0.5 \mathrm{~mm}$ ZOIs, respectively (Figure 6).

$\mathrm{MgO}-\mathrm{NPs}$ synthesized by brown algae Sargassum wighitii showed antifungal and broad-spectrum antibacterial potential against Proteus mirabilis, Staphylococcus aureus, Serratia marcescens, Escherichia coli, Salmonella typhimurium, and Pseudomonas aeruginosa (Pugazhendhi et al., 2019). Similarly, Deepak and coworkers demonstrated the facile fabrication of silver-NPs by the brown seaweed Sargassum wightii, and they reported bactericidal efficacy against $B$. subtilis, $B$. cereus, $P$. aeruginosa, Salmonella typhimurium, Enterococcus faecalis, and Shigella flexneri (Deepak et al., 2018).

MgO-NPs are metal-based, light nanoparticles with antimicrobial potential; it is totally resorbed and metabolized in the body. The minimal fungicidal and bactericidal inhibitory concentrations of MgO-NPs against prevailing infectious yeasts and bacteria must be determined to be applied clinically (Nguyen et al., 2018). Herein, MgO-NPs inhibited the growth of all the tested microbes. However, MIC was divergent for the two Grampositive bacteria, specifically $12.5 \mu \mathrm{g} \mathrm{mL}^{-1}$ was the MIC for $B$. subtilis and $50 \mu \mathrm{g} \mathrm{mL} \mathrm{m}^{-1}$ for $S$. aureus. In contrast, the concentration of MgO-NPs increased to 25 and $50 \mu \mathrm{g} \mathrm{mL}$ for realizing the MIC for the Gram-negative bacteria, $P$. aeruginosa, and $E$. coli, respectively. The antifungal properties of MgO-NPs were confirmed against C. albicans, registering the MIC value $12.5 \mu \mathrm{g} \mathrm{mL}^{-1}$.

The antibacterial properties of $\mathrm{MgO}-\mathrm{NPs}$ are attributed to various mechanisms as proposed by several authors as shown in Figure 7. These mechanisms include the enhancing reactive oxygen species (ROS) production, reaction of MgO-NPs with the bacterial cell wall and interfering with electron transport chains, the interaction between $\mathrm{Mg}^{2+}$ and active macromolecules inside the bacterial cells, and the production of alkaline conditions due to the release of $\mathrm{Mg}^{2+}$ inside the bacterial cells (Wong et al., 2020). The interaction between the bacterial cell wall and MgO-NPs might lead to the deformation of a cell wall structure and disrupt the electron transport chains, ultimately blocking the selective permeability function (Karthik et al., 2019). Also, this interaction led to the formation of toxic substances such as ${ }^{\bullet} \mathrm{OH}, \mathrm{H}_{2} \mathrm{O}_{2}$, and ${ }^{-} \mathrm{O}_{2}$ that irreversibly destroy the cell wall and its important components such as phospholipids. It might also interfere with protein and nucleic acids, which necessitates cell death (He et al., 2016). In addition, once MgO-NPs enter the cell, it presents their alkaline effects with the release of $\mathrm{Mg}^{2+}$ (Karthik et al., 2019; Abinaya et al., 2021). Likewise, the efficient toxicity of $\mathrm{MgO}-\mathrm{NPs}$ against diverse multidrug-resistant clinical pathogens 


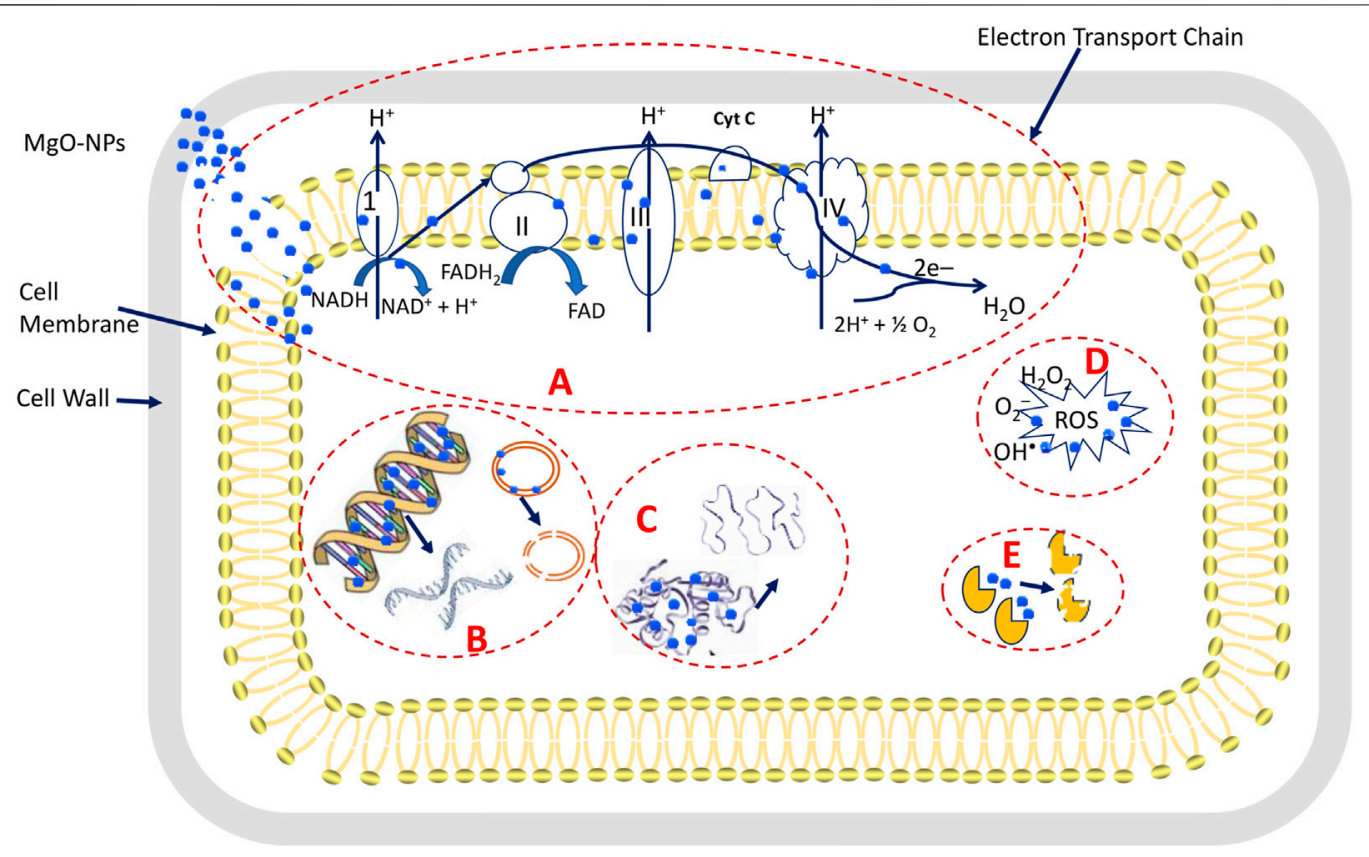

FIGURE 7 |Proposed antimicrobial mechanisms of MgO-NPs. (A) is the adhesion of MgO-NPs with the cell wall and electron transport chains ultimately disrupting the selective permeability function, (B) is the entrance of MgO-NPs into the cell and reacting with DNA and plasmids lead to genotoxicity, (C) is reacting of MgO-NPs with proteins ultimately to denaturation, (D) is the production of toxic substances that enhance the ROS that leads to macromolecules disruption. And (E) is blocking and changing the active sites in enzymes because of reacting with MgO-NPs.

makes it a good candidate for alternative medicine (He et al., 2016).

\section{In-Vitro Cytotoxicity of MgO-NPs Against Normal and Cancer Cells}

Various nanoparticles showed anticancer properties and can be used in cancer therapy or as targeted delivery systems for anticancer drugs (Chaudhary et al., 2020). The safe use of NPs as an antiproliferative agent against carcinoma requires evaluation of their side effects against normal cell lines and protein structure (Behzadi et al., 2018). Consequently, an MTT assay was used to evaluate the cytotoxicity of the phycosynthesized MgO-NPs against the human colon cancer cell lines (Caco-2) and the monkey's healthy cell lines (Vero). The MTT assay colorimetrically estimates the viability and proliferation of active cells regarding their metabolic reduction potency.

Seven concentrations of phyco-synthesized MgO-NPs (7.8, $15.6,31.25,62.5,125,250$, and $500 \mu \mathrm{g} \mathrm{mL}^{-1}$ ) were prepared to study their effect on the viability of Caco- 2 and Vero cell lines within $48 \mathrm{~h}$. MgO-NPs exhibited cytotoxic effects against normal and cancer cell lines in a dose-dependent manner. After the incubation with MgO-NPs for $48 \mathrm{~h}$, the cloned cells suffer a partial or complete breakdown of the characteristic integral monolayer of epithelial cells along with shrinkage, buoyancy and the cells appear grainy and spherical. Besides the changes that occurred in the typical epithelial morphology of the cell lines, there is a decrease in the cells population. These cellular modifications can be explained by the entry of MgO-NPs into

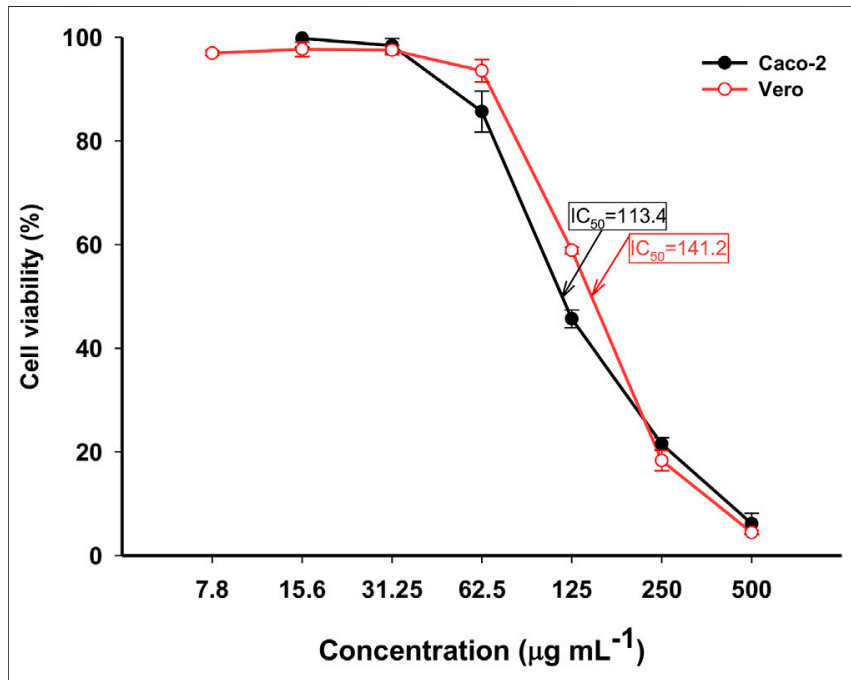

FIGURE 8 | The cytotoxic activity of MgO-NPs derived from Cystoseira crinita against normal (Vero) and cancer (Caco-2) cell lines.

mammalian cells via endocytosis or macro-pinocytosis followed by enhanced synthesis of reactive oxygen species (ROS) that damage the membrane mitochondrial potential and lead to the activation of the apoptotic pathway, which ends with cell death (Verma et al., 2020). Furthermore, the cellular damage induced by MgO-NPs is size-dependent, smaller-sized MgO NPs boosted the production of ROS, enhanced the interaction with cellular 
TABLE 1 | Larval and pupal toxicity of the phyco-synthesized MgO-NPs against the house fly Musca domestica.

\begin{tabular}{|c|c|c|c|c|c|c|c|}
\hline \multirow[t]{2}{*}{ Targeted instars } & \multicolumn{5}{|c|}{ Mortality percentages (\%) at different MgO-NPs concentrations } & \multirow[t]{2}{*}{$\mathrm{LC}_{50}$} & \multirow[t]{2}{*}{$\mathbf{L C}_{90}$} \\
\hline & $2 \mu \mathrm{g} \mathrm{mL}-1$ & $4 \mu \mathrm{g} \mathrm{mL} \mathrm{L}^{-1}$ & $6 \mu \mathrm{g} \mathrm{mL}-1$ & $8 \mu \mathrm{g} \mathrm{mL}{ }^{-1}$ & $10 \mu \mathrm{g} \mathrm{mL}-1$ & & \\
\hline I & $40.0 \pm 2.54$ & $61.6 \pm 3.78$ & $73.2 \pm 2.58$ & $94.4 \pm 1.14$ & $99.0 \pm 1.22$ & 3.08 & 7.46 \\
\hline$\|$ & $36.6 \pm 2.30$ & $57.2 \pm 1.48$ & $67.6 \pm 1.81$ & $86.2 \pm 2.58$ & $95.0 \pm 1.73$ & 3.49 & 8.89 \\
\hline III & $30.8 \pm 2.38$ & $42.4 \pm 2.50$ & $61.2 \pm 3.42$ & $72.2 \pm 3.11$ & $92.2 \pm 2.58$ & 4.64 & 10.4 \\
\hline Pupa & $22.4 \pm 2.60$ & $36.8 \pm 1.64$ & $51.0 \pm 2.64$ & $63.4 \pm 2.96$ & $81.0 \pm 3.16$ & 5.86 & 12.3 \\
\hline
\end{tabular}

Mortality averages are means $\pm S D$, of five replicates. No mortality was exhibited in the control. $L C_{50}$ is the lethal concentration that kills $50 \%$. $L C_{90}$ is the lethal concentration that kills $90 \%$ of the treated larva or pupa.

components, and improved membrane permeation to liberate $\mathrm{Mg}^{+}$ions (Ratan et al., 2020). Likewise, Pugazhendhi et al. have reported the cytotoxic potential of $\mathrm{MgO}-\mathrm{NPs}$ against lung cancer cell lines (A549), and observed cell rounding and shrinkage, membrane blabbing, apoptotic body formation, chromatin condensation, and reduced cell population after cells were incubated with MgO-NPs (Pugazhendhi et al., 2019).

Our results for the In-Vitro cytotoxicity assay demonstrated the dramatic effect of MgO-NPs on the viability of treated cell lines and increasing the concentration of MgO-NPs has significantly reduced cell viability (Figure 8). However, the biocolloidal $\mathrm{MgO}$ reduced the viability of cancer, as well as normal cell lines. The $\mathrm{IC}_{50}$ concentration against the Caco-2 cancer cell line was 113.4 , whereas it was $141.2 \mu \mathrm{g} \mathrm{mL}^{-1}$ for the normal Vero cell line. This threshold can be exploited clinically for selective targeting of cancer treatment. Accordingly, we claimed that MgO-NPs are more toxic to the cancer cell line than to the healthy cell line. Comparable cytotoxicity analysis concluded the enhanced anticancer potential of green synthesized $\mathrm{MgO}-\mathrm{NPs}$ against cancer cell line compared to the normal cell line (Behzadi et al., 2018; Pugazhendhi et al., 2019; Amina et al., 2020).

\section{Mosquitocidal Bioassay}

\section{Larvicidal and Pupicidal Activity}

Regardless of their annoying habits, more than humans and animals' pathogens are transmitted by physical association with house flies and it has been accused of transmitting many diseases such as cholera, infantile diarrhea, dysentery, typhoid fever, and an assortment of parasitic worms (Dahlem, 2009). Because they are closely related to humans, Musca domestica and its microbiome are of worth for detailed research (De Jonge et al., 2020). Therefore, we evaluated the larvicidal and pupicidal activities of phyco-synthesized MgO-NPs, in addition to their repellent properties.

The results listed in Table 1 manifested the effect of dipping the first, second, and third instar larvae and pupae of $M$. domestica in different concentrations $(2,4,6,8$, and $10 \mu \mathrm{g}$ $\mathrm{mL}^{-1}$ ) of phyco-synthesized MgO-NPs. The MgO-NPs caused larval death in a dose-dependent manner, and the mortality for first-stage larvae was 40 and $99 \%$ for concentrations of 2 and $10 \mu \mathrm{g} \mathrm{mL}{ }^{-1}$, respectively. In contrast the mortality for secondstage larvae was 36.6 and $95 \%$ when treated with 2 and $10 \mu \mathrm{g}$ $\mathrm{mL}^{-1}$ of MgO-NPs, respectively. Third instar larvae recorded a death rate of 30.8 and $92.2 \%$ corresponding to 2 and $10 \mu \mathrm{gL}^{-1}$ of MgO-NPs, respectively. Porbit program analysis calculated the $\mathrm{LC}_{50}$ concentrations by $3.08,3.49$, and $4.46 \mu \mathrm{gL}^{-1}$ and the $\mathrm{LC}_{90}$ concentrations by $7.46,8.89$, and $10.4 \mu \mathrm{g} \mathrm{mL} \mathrm{m}^{-1}$ for the first, second, and third instar larvae, respectively (Table 1).

Our specific feeding test demonstrated the potent toxicity of the phyco-synthesized MgO-NPs complex against the pupal phase of houseflies, $2 \mu \mathrm{g} \mathrm{mL}^{-1}$ of $\mathrm{MgO}-\mathrm{NPs}$ inhibited pupation by $22.4 \%$, and the maximum concentration of colloidal $\mathrm{MgO}$ solution $\left(10 \mu \mathrm{g} \mathrm{mL}^{-1}\right)$ inhibited pupation by $81 \%$. The concentrations of $\mathrm{LC}_{50}$ and $\mathrm{LC}_{90}$ against the pupal phase were estimated to be 5.86 and $12.3 \mu \mathrm{g} \mathrm{mL}^{-1}$, respectively. Hence, we established the highly toxic effect of phyco-synthesized MgO-NPs against the larval and pupal stages of the housefly in a dosedependent manner. Moreover, our results indicated that the phyco-synthesized MgO-NPs were more toxic to larvae than to pupae (Table 1).

Similarly, Fouda and coauthors reported the potency of the bio-synthesized MgO-NPs against different pupal and larvae instar of Anopheles stephensi, with $\mathrm{LC}_{50}$ values at $16.5 \mu \mathrm{g} \mathrm{mL}$ for pupa and 12.5-15.5 $\mu \mathrm{g} \mathrm{mL}^{-1}$ for I-IV larvae instar (Fouda et al., 2021a). Adesuji and coworkers reported the larvicidal efficiency of biosynthesized Ag-NPs against different instar larva phases of Culex quinquefasciatus (vector of lymphatic filariasis), recording the $\mathrm{LC}_{50}$ and $\mathrm{LC}_{90}$ values of 4.43 and $8.37 \mu \mathrm{g} \mathrm{mL} \mathrm{m}^{-1}$, respectively (Adesuji et al., 2016). In the same context, Ambrosia arborescens leaf extracts and Ag-NPs derived from these extracts proved larvicidal properties against the thirdstage larvae of Aedes aegypti mosquitoes (the main vector of Zina, dengue, and chikungunya infections). Moreover, Ag-NPs were more toxic than the plant extracts and scored the $\mathrm{LC}_{50}$ at $0.28 \mu \mathrm{g}$ $\mathrm{mL}^{-1}, \mathrm{LC}_{90}$ at $0.43 \mu \mathrm{g} \mathrm{mL} \mathrm{m}^{-1}$, whereas the aqueous extracts showed the massive values of $\mathrm{LC}_{50}$ and $\mathrm{LC}_{90}$ of 1844.61 and $6043.95 \mu \mathrm{g}$ $\mathrm{mL}^{-1}$, respectively (Morejón et al., 2018).

The mosquitocidal activities of MgO-NPs may be mainly attributed to their effectiveness in producing the elevated amount of ROS compared with other metal oxide nanoparticles, while being low toxic to plants, animals, and humans, besides their ability to damage the cell wall (Krishnamoorthy et al., 2012; Ma et al., 2018). Moreover, the increased $\mathrm{Mg}^{2+}$ concentration disturbs cellular equilibrium causing leakage of cell ingredients that end with mosquito cellular death (Pugazhendhi et al., 2019). The histological response to biogenic Ag-NPs reported that brush border and epithelial cells of the midgut area of the larvae of Aedes albopictus were highly affected (Ga'al et al., 2018). Moreover, metallic 
TABLE 2 | The efficacy of Cystoseira spp. to fabricate metal and metal oxides nanoparticles and compare them with the current study.

\begin{tabular}{|c|c|c|c|c|c|}
\hline $\begin{array}{l}\text { Cystoseira } \\
\text { spp. }\end{array}$ & NPs & Characterized by & $\begin{array}{l}\text { Shape and } \\
\text { size }\end{array}$ & Applications & Ref \\
\hline $\begin{array}{l}\text { Cystoseira } \\
\text { baccata }\end{array}$ & Au-NPs & $\begin{array}{l}\text { UV-vis spectroscopy, TEM, and } \\
\text { zeta potential }\end{array}$ & $\begin{array}{l}\text { Spherical shape with a size of } \\
8.4 \mathrm{~nm}\end{array}$ & $\begin{array}{l}\text { In-vitro cytotoxicity against normal and } \\
\text { cancer cell lines }\end{array}$ & $\begin{array}{l}\text { González-Ballesteros et al. } \\
\text { (2017) }\end{array}$ \\
\hline C. myrica & $\begin{array}{l}\mathrm{CuO}- \\
\mathrm{NPs}\end{array}$ & $\begin{array}{l}\text { UV-Vis spectroscopy, TEM, } \\
\text { DLS, XRD, and FTIR. }\end{array}$ & $\begin{array}{l}\text { Spherical shape with a size of } \\
11-80 \mathrm{~nm}\end{array}$ & In-Vitro cytotoxicity & Mohamed et al. (2021) \\
\hline C. crinita & $\begin{array}{l}\mathrm{ZnO}- \\
\mathrm{NPs}\end{array}$ & $\begin{array}{l}\text { UV-Vis spectroscopy, TEM, FT- } \\
\text { IR, XRD, and DLS }\end{array}$ & $\begin{array}{l}\text { Multilayered rectangular particles } \\
\text { with sizes of } 23-200 \mathrm{~nm}\end{array}$ & Antimicrobial and antioxidant & Elrefaey et al. (2022) \\
\hline C. barbata & Ag-NPs & $\begin{array}{l}\text { UV-Vis spectroscopy, FT-IR, } \\
\text { DLS, and TEM }\end{array}$ & $\begin{array}{l}\text { Spherical shape with a size of } \\
12.86\end{array}$ & Anti-Candida & Alghuthaymi et al. (2021) \\
\hline C. barbata & Se-NPs & UV-Vis. FT-IR, DLS, and TEM & $\begin{array}{l}\text { Spherical shape with a size of } \\
12.86\end{array}$ & Anti-Candida & Alghuthaymi et al. (2021) \\
\hline C. crinita & $\begin{array}{l}\mathrm{MgO}- \\
\mathrm{NPS}\end{array}$ & $\begin{array}{l}\text { UV-Vis, FT-IR, XRD, SEM-EDX, } \\
\text { TEM, and XPS }\end{array}$ & $\begin{array}{l}\text { Spherical shape with size of } \\
3-18 \mathrm{~nm}\end{array}$ & $\begin{array}{l}\text { Antimicrobial, in-vitro cytotoxicity, } \\
\text { larvicidal, and repellence activity }\end{array}$ & Current study \\
\hline
\end{tabular}

nanoparticles might bind to $\mathrm{P}$ and $\mathrm{S}$ in nucleic acids and proteins, respectively, which leads to the reduced permeability of the membrane, denaturation of enzymes and organelles ending in cell death. In addition, metal and metal oxide nanoparticles regulate important genes of insects, decrease releasing of gonadotrophin and protein synthesis, which leads to reproductive failure and damage to growth (Benelli, 2018). Based on these results, the phyco-synthesized MgO-NPs could be introduced as an efficient candidate for the biological control of mosquitoes.

\section{Repellent Activity}

Arthropods land on the skin and bite, which can be a carrier of some diseases. Repellents are chemicals that prohibit arthropods from landing on the skin and thus prevent bites and the resulting disease transmission (Tavares et al., 2018). Although synthetic insecticides and repellents are easy to use and fast-acting, their continued use disrupts the ecological balance and the consequent damage to nontarget organisms, as well as the development of insect resistance, in addition to the cost of these chemicals limiting their use in low-income countries (Fernandes et al., 2021). As research continues to create economical and environmentally safe alternatives that have insecticidal properties, in this research, we explored the properties of phyco-synthesized MgO-NPs as insect repellent. Here we set a time-based bioassay to explore the mosquito-repellent properties of the phyco-synthesized MgO-NPs against adult domestic mosquitoes and recorded observations after 12, 24, 48, and $72 \mathrm{~h}$ of incubation. The results confirmed the properties of phyco-synthesized $\mathrm{MgO}-\mathrm{NPs}$ as a mosquito repellent in a time-dependent manner.

The experiment was conducted using 1.0\% MgO-NPs at a concentration of $10 \mu \mathrm{g} \mathrm{mL} \mathrm{m}^{-1}$. After $12 \mathrm{~h}$ from the beginning of the test, the repellent rate was $63 \pm 0.23 \%$, whereas the repellency percentages after $24,48,72 \mathrm{~h}$ were increased to be $77.9 \pm 0.34$, $84.9 \pm 0.31$, and $96.8 \pm 0.213 \%$, respectively. In the same regard, Hassan and coauthors studied the insecticidal properties of the myco-synthesized MgO-NPs against Culex pipiens and they reported the larvicidal effect and repellent potency of quite low concentrations of MgO-NPs against the common house mosquito (Hassan et al., 2021). Recently, the mosquito- repellent efficiency of Phyto-derived Ag-NPs was confirmed against four-vector mosquitoes; different concentrations of AgNPs (50, 75, and $100 \mathrm{mg} \mathrm{mL} \mathrm{mL}^{-1}$ ) manifested $6.25-60.0 \%$ repellences against week-old female mosquitoes of Culex quinquefasciatus, Anopheles gambiae, Anopheles maculatus, and Aedes aegypti (Akintelu et al., 2021). Likewise, a recently published study concluded the successful fabrication of $\mathrm{MgO}$ NPs through harnessing metabolites of Penicillium chrysogenum and exhibited the broad-spectrum antibacterial activity, larvicidal, and pupicidal activity coupled with long-lasting mosquito-repellent properties against adults of Anopheles stephensi (Fouda et al., 2021a). As the phyco-synthesized MgO-NPs obtained in the current study are one-step easy synthesized, inexpensive, and attain several biological properties, we recommend exploiting them in medicinal applications as well as in the designing of topical mosquito repellents to control mosquito-borne diseases, especially in endemic countries.

\section{Comparison Study}

The efficacy of Cystoseria spp. to fabricate different metal and metal oxides nanoparticles with varied shapes, sizes, and applications compared with the current study is shown in Table 2. As shown, the polysaccharide fucoidan secreted by Cystoseira barbata have the efficacy to fabricate spherical AgNPs and Se-NPs with sizes of 12.86 and $16.18 \mathrm{~nm}$, respectively, and showed anti-Candida activity (Alghuthaymi et al., 2021). Moreover, the spherical CuO-NPs with the size of 11-80 nm were successfully synthesized by the aqueous extract of Cystoseira myrica and exhibit high activity against two cancerous cell lines, namely, HepG2 and MCF-7 (Mohamed et al., 2021). In a recent study, the aqueous extract of $C$. crinita was used to form rectangular $\mathrm{ZnO}$-NPs with sizes ranging between 23 and $200 \mathrm{~nm}$ and showed antimicrobial and antioxidant activity (Elrefaey et al., 2022). To the best of our knowledge, this is the first report for the green synthesis of $\mathrm{MgO}-\mathrm{NPs}$ using an aqueous extract of $C$. crinita. In the current study, a small size $(3-18 \mathrm{~nm})$ of spherical $\mathrm{MgO}-\mathrm{NPs}$ was successfully formed by brown algae, C. crinita, and exhibited varied activity including antimicrobial, in-vitro cytotoxicity, larvicidal, and repellence activity. 


\section{CONCLUSION}

In the current study, the aqueous extract of C. crinita was used as a reducing and capping/stabilizing agent for the green synthesis of MgO-NPs. The color change of algal aqueous extract from pale yellow to yellowish-brown as well as observing the maximum SPR peak at $320 \mathrm{~nm}$ confirmed the MgO-NPs formation. The crystalline structure and spherical shape with sizes of 3-18 nm were investigated by XRD and TEM analyses. Also, the SEM-EDX and XPS revealed that the main components of the resultant are $\mathrm{Mg}$ and $\mathrm{O}$. The activities of algal-mediated green synthesis of $\mathrm{MgO}-\mathrm{NPs}$ were dose-dependent. The synthesized MgO-NPs showed excellent antimicrobial activity against various pathogenic bacteria, and unicellular fungi. Data showed that the synthesized $\mathrm{MgO}-\mathrm{NPs}$ showed high selectivity to destroy cancer cell lines at low concentrations compared with normal cell lines. The biosynthesized MgO-NPs showed larvicidal/ pupicidal of $M$. domestica at low concentration against I, II, III instar larvae, and pupa. Moreover, it exhibited a repellence activity against adults of $M$. domestica with percentages of $63 \pm$ $0.23 \%, 77.9 \pm 0.34 \%, 84.9 \pm 0.31 \%$, and $96.8 \pm 0.213 \%$ after 12,24 ,

\section{REFERENCES}

Abinaya, S., Kavitha, H. P., Prakash, M., and Muthukrishnaraj, A. (2021). Green Synthesis of Magnesium Oxide Nanoparticles and its Applications: A Review. Sust. Chem. Pharm. 19, 100368. doi:10.1016/j.scp.2020.100368

Adesuji, E. T., Oluwaniyi, O. O., Adegoke, H. I., Moodley, R., Labulo, A. H., Bodede, O. S., et al. (2016). Investigation of the Larvicidal Potential of Silver Nanoparticles against Culex quinquefasciatus: A Case of a Ubiquitous Weed as a Useful Bioresource. J. Nanomater. 2016, 4363751. doi:10.1155/2016/ 4363751

Akintelu, S. A., Folorunso, A. S., Oyebamiji, A. K., and Olugbeko, S. C. (2021). Mosquito Repellent and Antibacterial Efficiency of Facile and Low-Cost Silver Nanoparticles Synthesized Using the Leaf Extract of Morinda citrifolia. Plasmonics 16, 1645-1656. doi:10.1007/s11468-021-01428-3

Alghuthaymi, M. A., El-Sersy, Z. R., Tayel, A. A., Alsieni, M. A., and Abd El Maksoud, A. I. (2021). Anticandidal Potentiality of Biosynthesized and Decorated Nanometals with Fucoidan. Green. Process. Synth. 10, 811-823. doi:10.1515/gps-2021-0076

Amina, M., Al Musayeib, N. M., Alarfaj, N. A., El-Tohamy, M. F., Oraby, H. F., Al Hamoud, G. A., et al. (2020). Biogenic green Synthesis of MgO Nanoparticles Using Saussurea costus Biomasses for a Comprehensive Detection of Their Antimicrobial, Cytotoxicity against MCF-7 Breast Cancer Cells and Photocatalysis Potentials. PLoS One 15, e0237567. doi:10.1371/journal.pone. 0237567

Ammulu, M. A., Vinay Viswanath, K., Giduturi, A. K., Vemuri, P. K., Mangamuri, U., and Poda, S. (2021). Phytoassisted Synthesis of Magnesium Oxide Nanoparticles from Pterocarpus Marsupium rox.B Heartwood Extract and its Biomedical Applications. J. Genet. Eng. Biotechnol. 19, 21. doi:10.1186/ s43141-021-00119-0

Badawy, A. A., Abdelfattah, N. A. H., Salem, S. S., Awad, M. F., and Fouda, A. (2021). Efficacy Assessment of Biosynthesized Copper Oxide Nanoparticles (CuO-NPs) on Stored Grain Insects and Their Impacts on Morphological and Physiological Traits of Wheat (Triticum aestivum L.) Plant. Biology 10, 233. doi:10.3390/biology10030233

Baig, N., Kammakakam, I., and Falath, W. (2021). Nanomaterials: a Review of Synthesis Methods, Properties, Recent Progress, and Challenges. Mater. Adv. 2, 1821-1871. doi:10.1039/d0ma00807a

Bartis, E. A., Luan, P., Knoll, A. J., Hart, C., Seog, J., and Oehrlein, G. S. (2015). Polystyrene as a Model System to Probe the Impact of Ambient Gas Chemistry on Polymer Surface Modifications Using Remote Atmospheric Pressure Plasma
48 , and $72 \mathrm{~h}$, respectively. The obtained data confirm the power of active substances produced by brown algae, $C$. crinita to fabricate MgO-NPs that are characterized by their activity as well as biocompatibility into various biomedical applications.

\section{DATA AVAILABILITY STATEMENT}

The data used to support the findings of this study are available from the corresponding author upon request.

\section{AUTHOR CONTRIBUTIONS}

AF, AE, MA-R, EE-B, MA, SH, and $\mathrm{MH}$ contributed to conceptualization, methodology, software, validation, formal analysis, investigation, resources, data curation, writing-original draft preparation, writing-review and editing; ZA-F contributed to resources, validation, funding acquisition, writing-original draft preparation. All authors have read and agreed to the published version of the manuscript.

under Well-Controlled Conditions. Biointerphases 10, 029512. doi:10.1116/1. 4919410

Behzadi, E., Sarsharzadeh, R., Nouri, M., Attar, F., Akhtari, K., Shahpasand, K., et al. (2018). Albumin Binding and Anticancer Effect of Magnesium Oxide Nanoparticles. Int. J. Nanomedicine 14, 257-270. doi:10.2147/ijn.s186428

Benelli, G. (2018). Mode of Action of Nanoparticles against Insects. Environ. Sci. Pollut. Res. 25, 12329-12341. doi:10.1007/s11356-018-1850-4

Bruno De Sousa, C., Gangadhar, K. N., Macridachis, J., Pavão, M., Morais, T. R., Campino, L., et al. (2017). Cystoseira Algae (Fucaceae): Update on Their Chemical Entities and Biological Activities. Tetrahedron: Asymmetry 28, 1486-1505. doi:10.1016/j.tetasy.2017.10.014

Campbell, M. M. (1983). A Test for Repellency to Non-biting Flies and a Comparison of Repellents using Musca domestica L. Pestic. Sci. 14, 199-212. doi:10.1002/ps.2780140215

Cao, X., Zhao, H., Liu, X., Luo, H.-H., and Liu, R. (2020). Preparation of Petal-like Magnesium Hydroxide Particles by Adding Sulfate Ions. J. Cryst. Growth 550, 125841. doi:10.1016/j.jcrysgro.2020.125841

Chaudhary, R., Nawaz, K., Khan, A. K., Hano, C., Abbasi, B. H., and Anjum, S. (2020). An Overview of the Algae-Mediated Biosynthesis of Nanoparticles and Their Biomedical Applications. Biomolecules 10, 1498. doi:10.3390/ biom 10111498

Coates, J. (2006). "Interpretation of Infrared Spectra, A Practical Approach," in Encycl. Anal. Chem. Appl. Theory Instrum (Wiley Online Library).

Dahlem, G. A. (2009). "House Fly," in Encyclopedia of Insects (Elsevier), 469-470. doi:10.1016/b978-0-12-374144-8.00134-x

Dang, L., Nai, X., Dong, Y., and Li, W. (2017). Functional Group Effect on Flame Retardancy, thermal, and Mechanical Properties of Organophosphorus-Based Magnesium Oxysulfate Whiskers as a Flame Retardant in Polypropylene. RSC Adv. 7, 21655-21665. doi:10.1039/c7ra02863f

De Jonge, N., Michaelsen, T. Y., Ejbye-Ernst, R., Jensen, A., Nielsen, M. E., Bahrndorff, S., et al. (2020). Housefly (Musca domestica L.) Associated Microbiota across Different Life Stages. Sci. Rep. 10, 7842. doi:10.1038/ s41598-020-64704-y

Deepak, P., Amutha, V., Birundha, R., Sowmiya, R., Kamaraj, D. C., Velramar, B., et al. (2018). Facile green Synthesis of Nanoparticles from Brown Seaweed Sargassum Wightii and its Biological Application Potential. Adv. Nat. Sci. Nanoscience Nanotechnology 9, 035019. doi:10.1088/2043-6254/aadc4a

El-Belely, E. F., Farag, M. M. S., Said, H. A., Amin, A. S., Azab, E., Gobouri, A. A., et al. (2021). Green Synthesis of Zinc Oxide Nanoparticles (ZnO-NPs) Using Arthrospira Platensis (Class: Cyanophyceae) and Evaluation of Their Biomedical Activities. Nanomaterials (Basel) 11, 95. doi:10.3390/nano11010095 
Elrefaey, A. A. K., El-Gamal, A. D., Hamed, S. M., and El-Belely, E. F. (2022). Algaemediated Biosynthesis of Zinc Oxide Nanoparticles from Cystoseira crinita (Fucales; Sargassaceae) and It's Antimicrobial and Antioxidant Activities. Egypt. J. Chem. 65, 1-2. doi:10.21608/ejchem.2021.87722.4231

Essien, E. R., Atasie, V. N., Okeafor, A. O., and Nwude, D. O. (2020). Biogenic Synthesis of Magnesium Oxide Nanoparticles Using Manihot esculenta (Crantz) Leaf Extract. Int. Nano Lett. 10, 43-48. doi:10.1007/s40089-019-00290-w

Fedlheim, D. L., and Foss, C. A. (2001). Metal Nanoparticles: Synthesis, Characterization, and Applications. London: Taylor 8 Francis Group. doi:10. 1201/9780367800475

Fernandes, D. A., Rique, H. L., De Oliveira, L. H. G., Santos, W. G. S., De Souza, M. D. F. V., and Da Cruz Nunes, F. (2021). Ovicidal, Pupicidal, Adulticidal, and Repellent Activity of Helicteres velutina K. Schum against Aedes aegypti L. (Diptera: Culicidae). Braz. J. Vet. Med. 43, e102120. doi:10.29374/2527-2179. bjvm112120

Fouda, A., El-Din Hassan, S., Salem, S. S., and Shaheen, T. I. (2018). In-Vitro Cytotoxicity, Antibacterial, and UV protection Properties of the Biosynthesized Zinc Oxide Nanoparticles for Medical Textile Applications. Microb. Pathogenesis 125, 252-261. doi:10.1016/j.micpath.2018.09.030

Fouda, A., Hassan, S. E.-D., Abdo, A. M., and El-Gamal, M. S. (2020). Antimicrobial, Antioxidant and Larvicidal Activities of Spherical Silver Nanoparticles Synthesized by Endophytic Streptomyces spp. Biol. Trace Elem. Res. 195, 707-724. doi:10.1007/s12011-019-01883-4

Fouda, A., Awad, M. A., Eid, A. M., Saied, E., Barghoth, M. G., Hamza, M. F., et al. (2021a). An Eco-Friendly Approach to the Control of Pathogenic Microbes and Anopheles stephensi Malarial Vector Using Magnesium Oxide Nanoparticles (Mg-NPs) Fabricated by Penicillium chrysogenum. Int. J. Mol. Sci. 22, 5096. doi:10.3390/ijms22105096

Fouda, A., Eid, A. M., Elsaied, A., El-Belely, E. F., Barghoth, M. G., Azab, E., et al. (2021b). Plant Growth-Promoting Endophytic Bacterial Community Inhabiting the Leaves of Pulicaria Incisa (Lam.) DC Inherent to Arid Regions. Plants (Basel) 10, 76. doi:10.3390/plants10010076

Fouda, A., Hassan, S. E.-D., Abdel-Rahman, M. A., Farag, M. M. S., Shehal-Deen, A., Mohamed, A. A., et al. (2021c). Catalytic Degradation of Wastewater from the Textile and Tannery Industries by green Synthesized Hematite ( $\mathrm{a}-\mathrm{Fe} 2 \mathrm{O} 3$ ) and Magnesium Oxide (MgO) Nanoparticles. Curr. Res. Biotechnol. 3, 29-41. doi:10.1016/j.crbiot.2021.01.004

Fouda, A., Hassan, S. E.-D., Saied, E., and Azab, M. S. (2021d). An EcoFriendly Approach to Textile and Tannery Wastewater Treatment Using Maghemite Nanoparticles ( $\gamma$-Fe2O3-NPs) Fabricated by Penicillium expansum Strain (K-W). J. Environ. Chem. Eng. 9, 104693. doi:10.1016/ j.jece.2020.104693

Fouda, A., Hassan, S. E.-D., Saied, E., and Hamza, M. F. (2021e). Photocatalytic Degradation of Real Textile and Tannery Effluent Using Biosynthesized Magnesium Oxide Nanoparticles (MgO-NPs), Heavy Metal Adsorption, Phytotoxicity, and Antimicrobial Activity. J. Environ. Chem. Eng. 9, 105346. doi:10.1016/j.jece.2021.105346

Ga'al, H., Fouad, H., Mao, G., Tian, J., and Jianchu, M. (2018). Larvicidal and Pupicidal Evaluation of Silver Nanoparticles Synthesized Using Aquilaria Sinensis and Pogostemon Cablin Essential Oils against Dengue and Zika Viruses Vector Aedes albopictus Mosquito and its Histopathological Analysis. Artif. Cell Nanomed Biotechnol 46, 1171-1179. doi:10.1080/ 21691401.2017.1365723

González-Ballesteros, N., Prado-López, S., Rodríguez-González, J. B., Lastra, M., and Rodríguez-Argüelles, M. C. (2017). Green Synthesis of Gold Nanoparticles Using Brown Algae Cystoseira Baccata : Its Activity in colon Cancer Cells. Colloids Surf. B: Biointerfaces 153, 190-198. doi:10.1016/j.colsurfb.2017.02.020

Gu, H., Chen, X., Chen, F., Zhou, X., and Parsaee, Z. (2018). Ultrasound-assisted Biosynthesis of CuO-NPs Using Brown Alga Cystoseira Trinodis: Characterization, Photocatalytic AOP, DPPH Scavenging and Antibacterial Investigations. Ultrason. Sonochem. 41, 109-119. doi:10.1016/j.ultsonch.2017. 09.006

Hamza, M. F., Abdel-Rahman, A. A.-H., Wei, Y., Mira, H. I., and Guibal, E. (2019). Synthesis and Adsorption Characteristics of Grafted Hydrazinyl Amine Magnetite-Chitosan for $\mathrm{Ni}(\mathrm{II})$ and $\mathrm{Pb}(\mathrm{II})$ Recovery. Chem. Eng. J. 362, 310-324. doi:10.1016/j.cej.2018.11.225

Hamza, M. F., Lu, S., Salih, K. A. M., Mira, H., Dhmees, A. S., Fujita, T., et al. (2020a). As(V) Sorption from Aqueous Solutions Using Quaternized Algal/ polyethyleneimine Composite Beads. Sci. Total Environ. 719, 137396. doi:10. 1016/j.scitotenv.2020.137396

Hamza, M. F., Wei, Y., and Guibal, E. (2020b). Quaternization of Algal/PEI Beads (A New Sorbent): Characterization and Application to Scandium Sorption from Aqueous Solutions. Chem. Eng. J. 383, 123210. doi:10.1016/ j.cej.2019.123210

Hamza, M. F., Hamad, N. A., Hamad, D. M., Khalafalla, M. S., Abdel-Rahman, A. A. H., Zeid, I. F., et al. (2021a). Synthesis of Eco-Friendly Biopolymer, AlginateChitosan Composite to Adsorb the Heavy Metals, $\mathrm{Cd}(\mathrm{II})$ and $\mathrm{Pb}(\mathrm{II})$ from Contaminated Effluents. Materials 14, 2189. doi:10.3390/ma14092189

Hamza, M. F., Salih, K. A. M., Abdel-Rahman, A. A.-H., Zayed, Y. E., Wei, Y., Liang, J., et al. (2021b). Sulfonic-functionalized Algal/PEI Beads for Scandium, Cerium and Holmium Sorption from Aqueous Solutions (Synthetic and Industrial Samples). Chem. Eng. J. 403, 126399. doi:10.1016/j.cej.2020.126399

Hassan, S. E., Fouda, A., Saied, E., Farag, M. M. S., Eid, A. M., Barghoth, M. G., et al. (2021). Rhizopus Oryzae-mediated Green Synthesis of Magnesium Oxide Nanoparticles (MgO-NPs): A Promising Tool for Antimicrobial, Mosquitocidal Action, and Tanning Effluent Treatment. J. Fungi 7, 372. doi:10.3390/jof7050372

He, Y., Ingudam, S., Reed, S., Gehring, A., Strobaugh, T. P., and Irwin, P. (2016). Study on the Mechanism of Antibacterial Action of Magnesium Oxide Nanoparticles against Foodborne Pathogens. J. Nanobiotechnol 14, 54. doi:10.1186/s12951-016-0202-0

He, C., Salih, K. A. M., Wei, Y., Mira, H., Abdel-Rahman, A. A. H., Elwakeel, K. Z., et al. (2021). Efficient Recovery of Rare Earth Elements (Pr(III) and Tm(III)) from Mining Residues Using a New Phosphorylated Hydrogel (Algal Biomass/ PEI). Metals 11, 294. doi:10.3390/met11020294

Hogsette, J. A. (1992). New Diets for Production of House Flies and Stable Flies (Diptera: Muscidae) in the Laboratory. J. Econ. Entomol. 85, 2291-2294. doi:10. 1093/jee/85.6.2291

Huang, L., Li, D., Lin, Y., Evans, D. G., and Duan, X. (2005). Influence of Nano$\mathrm{MgO}$ Particle Size on Bactericidal Action against Bacillus subtilis Var. niger. Chin.Sci.Bull. 50, 514-519. doi:10.1007/bf02897474

Jacob, J. M., Ravindran, R., Narayanan, M., Samuel, S. M., Pugazhendhi, A., and Kumar, G. (2021). Microalgae: A Prospective Low Cost green Alternative for Nanoparticle Synthesis. Curr. Opin. Environ. Sci. Health 20, 100163. doi:10. 1016/j.coesh.2019.12.005

Jena, J., Pradhan, N., Nayak, R. R., Dash, B. P., Sukla, L. B., Panda, P. K., et al. (2014). Microalga Scenedesmus sp.: A Potential Low-Cost green Machine for Silver Nanoparticle Synthesis. J. Microbiol. Biotechnol. 24, 522-533. doi:10. 4014/jmb.1306.06014

Jurado-López, B., Vieira, R. S., Rabelo, R. B., Beppu, M. M., Casado, J., and Rodríguez-Castellón, E. (2017). Formation of Complexes between Functionalized Chitosan Membranes and Copper: A Study by Angle Resolved XPS. Mater. Chem. Phys. 185, 152-161. doi:10.1016/j. matchemphys.2016.10.018

Karthik, K., Dhanuskodi, S., Gobinath, C., Prabukumar, S., and Sivaramakrishnan, S. (2019). Fabrication of $\mathrm{MgO}$ Nanostructures and its Efficient Photocatalytic, Antibacterial and Anticancer Performance. J. Photochem. Photobiol. B: Biol. 190, 8-20. doi:10.1016/j.jphotobiol.2018.11.001

Kim, S.-K., and Chojnacka, K. (2015). Marine Algae Extracts, 2 Volume Set: Processes, Products, and Applications. John Wiley \& Sons.

Krishnamoorthy, K., Manivannan, G., Kim, S. J., Jeyasubramanian, K., and Premanathan, M. (2012). Antibacterial Activity of MgO Nanoparticles Based on Lipid Peroxidation by Oxygen Vacancy. J. Nanopart Res. 14, 1063. doi:10.1007/s11051-012-1063-6

Kumar, H., Bhardwaj, K., Kuča, K., Kalia, A., Nepovimova, E., Verma, R., et al. (2020). Flower-Based Green Synthesis of Metallic Nanoparticles: Applications beyond Fragrance. Nanomaterials 10, 766. doi:10.3390/nano10040766

Lashin, I., Fouda, A., Gobouri, A. A., Azab, E., Mohammedsaleh, Z. M., and Makharita, R. R. (2021). Antimicrobial and In Vitro Cytotoxic Efficacy of Biogenic Silver Nanoparticles (Ag-NPs) Fabricated by Callus Extract of Solanum Incanum L. Biomolecules 11, 341. doi:10.3390/biom11030341

Le Febvrier, A., Jensen, J., and Eklund, P. (2017). Wet-cleaning of $\mathrm{MgO}(001)$ : Modification of Surface Chemistry and Effects on Thin Film Growth Investigated by X-ray Photoelectron Spectroscopy and Time-Of-Flight Secondary Ion Mass Spectroscopy. J. Vacuum Sci. Tech. A: Vacuum, Surf. Films 35, 021407. doi:10.1116/1.4975595 
Lu, S., Chen, L., Hamza, M. F., He, C., Wang, X., Wei, Y., et al. (2019). Amidoxime Functionalization of a Poly(acrylonitrile)/silica Composite for the Sorption of Ga(III) - Application to the Treatment of Bayer Liquor. Chem. Eng. J. 368, 459-473. doi:10.1016/j.cej.2019.02.094

Ma, B., Yu, N., Han, Y., Gao, M., Wang, S., Li, S., et al. (2018). Effect of Magnesium Oxide Nanoparticles on Microbial Diversity and Removal Performance of Sequencing Batch Reactor. J. Environ. Manage. 222, 475-482. doi:10.1016/j. jenvman.2018.05.089

M. Mohamed et al., R. M., Fawzy, R., Shehab, R. A., Ali, D. M., Salah El Din, R. A., and Abd El Fatah, H. M. (2021). Green Biosynthesis, Structural Characterization and Anticancer Activity of Copper Oxide Nanoparticles from the Brown Alga Cystoseira myrica. Egypt. J. Aquat. Biolo. Fish. 25, 341-358. doi:10.21608/ejabf.2021.189069

Moorthy, S. K., Ashok, C., Rao, K. V., and Viswanathan, C. (2015). Synthesis and Characterization of Mgo Nanoparticles by Neem Leaves through Green Method. Mater. Today Proc. 2, 4360-4368. doi:10.1016/j.matpr.2015.10.027

Morejón, B., Pilaquinga, F., Domenech, F., Ganchala, D., Debut, A., and Neira, M. (2018). Larvicidal Activity of Silver Nanoparticles Synthesized Using Extracts of Ambrosia Arborescens (Asteraceae) to Control Aedes aegypti L. (Diptera: Culicidae). J. Nanotechnology 2018, 6917938. doi:10.1155/2018/6917938

Mukherjee, A., Sarkar, D., and Sasmal, S. (2021). A Review of Green Synthesis of Metal Nanoparticles Using Algae. Front. Microbiol. 12, 899. doi:10.3389/fmicb. 2021.693899

Namvar, F., Azizi, S., Ahmad, M. B., Shameli, K., Mohamad, R., Mahdavi, M., et al. (2014). Green Synthesis and Characterization of Gold Nanoparticles Using the marine Macroalgae Sargassum muticum. Res. Chem. Intermed 41, 5723-5730. doi:10.1007/s11164-014-1696-4

Nguyen, N.-Y. T., Grelling, N., Wetteland, C. L., Rosario, R., and Liu, H. (2018). Antimicrobial Activities and Mechanisms of Magnesium Oxide Nanoparticles (nMgO) against Pathogenic Bacteria, Yeasts, and Biofilms. Sci. Rep. 8, 16260. doi:10.1038/s41598-018-34567-5

Ogunyemi, S. O., Zhang, F., Abdallah, Y., Zhang, M., Wang, Y., Sun, G., et al. (2019). Biosynthesis and Characterization of Magnesium Oxide and Manganese Dioxide Nanoparticles Using Matricaria Chamomilla L. Extract and its Inhibitory Effect on Acidovorax Oryzae Strain RS-2. Artif. Cell Nanomedicine, Biotechnol. 47, 2230-2239. doi:10.1080/21691401.2019.1622552

Parial, D., Patra, H. K., Roychoudhury, P., Dasgupta, A. K., and Pal, R. (2012). Gold Nanorod Production by Cyanobacteria-A green Chemistry Approach. J. Appl. Phycol 24, 55-60. doi:10.1007/s10811-010-9645-0

Poinern, G. E. J. (2014). A Laboratory Course in Nanoscience and Nanotechnology. Boca Raton: CRC Press.

Pugazhendhi, A., Prabhu, R., Muruganantham, K., Shanmuganathan, R., and Natarajan, S. (2019). Anticancer, Antimicrobial and Photocatalytic Activities of green Synthesized Magnesium Oxide Nanoparticles (MgONPs) Using Aqueous Extract of Sargassum wightii. J. Photochem. Photobiol. B: Biol. 190, 86-97. doi:10.1016/j.jphotobiol.2018.11.014

Ramanujam, K., and Sundrarajan, M. (2014). Antibacterial Effects of Biosynthesized MgO Nanoparticles Using Ethanolic Fruit Extract of Emblica officinalis. J. Photochem. Photobiol. B: Biol. 141, 296-300. doi:10.1016/j. jphotobiol.2014.09.011

Ratan, Z. A., Haidere, M. F., Nurunnabi, M., Shahriar, S. M., Ahammad, A. J. S., Shim, Y. Y., et al. (2020). Green Chemistry Synthesis of Silver Nanoparticles and Their Potential Anticancer Effects. Cancers 12, 855. doi:10.3390/ cancers 12040855

Saied, E., Eid, A. M., Hassan, S. E., Salem, S. S., Radwan, A. A., Halawa, M., et al. (2021). The Catalytic Activity of Biosynthesized Magnesium Oxide Nanoparticles (MgO-NPs) for Inhibiting the Growth of Pathogenic Microbes, Tanning Effluent Treatment, and Chromium Ion Removal. Catalysts 11, 821. doi:10.3390/catal11070821

Salem, S. S., and Fouda, A. (2021). Green Synthesis of Metallic Nanoparticles and Their Prospective Biotechnological Applications: an Overview. Biol. Trace Elem. Res. 199, 344-370. doi:10.1007/s12011-020-02138-3

Shaheen, T. I., and Fouda, A. (2018). Green Approach for One-Pot Synthesis of Silver Nanorod Using Cellulose Nanocrystal and Their Cytotoxicity and
Antibacterial Assessment. Int. J. Biol. Macromolecules 106, 784-792. doi:10. 1016/j.ijbiomac.2017.08.070

Shaheen, T. I., Fouda, A., and Salem, S. S. (2021). Integration of Cotton Fabrics with Biosynthesized $\mathrm{CuO}$ Nanoparticles for Bactericidal Activity in the Terms of Their Cytotoxicity Assessment. Ind. Eng. Chem. Res. 60, 1553-1563. doi:10. 1021/acs.iecr.0c04880

Sharma, S. K., Khan, A. U., Khan, M., Gupta, M., Gehlot, A., Park, S., et al. (2020). Biosynthesis of MgO Nanoparticles Using Annona Squamosa Seeds and its Catalytic Activity and Antibacterial Screening. Micro Nano Lett. 15, 30-34. doi: $10.1049 / \mathrm{mnl} .2019 .0358$

Sinthusiri, J., and Soonwera, M. (2010). "Effect of Herbal Essential Oils against Larvae, Pupae and Adults of House Fly (Musca domestica L.: Diptera)," in Proceedings of the 16th Asian Agricultural Symposium and 1st International Symposium on Agricultural Technology, 639-642.

Soliman, A. M., Abdel-Latif, W., Shehata, I. H., Fouda, A., Abdo, A. M., and Ahmed, Y. M. (2021). Green Approach to Overcome the Resistance Pattern of Candida Spp. Using Biosynthesized Silver Nanoparticles Fabricated by Penicillium chrysogenum F9. Biol. Trace Elem. Res. 199, 800-811. doi:10. 1007/s12011-020-02188-7

Tavares, M., Da Silva, M. R. M., De Oliveira De Siqueira, L. B., Rodrigues, R. A. S., Bodjolle-D'almeida, L., Dos Santos, E. P., et al. (2018). Trends in Insect Repellent Formulations: A Review. Int. J. Pharmaceutics 539, 190-209. doi:10.1016/j.ijpharm.2018.01.046

Uzair, B., Liaqat, A., Iqbal, H., Menaa, B., Razzaq, A., Thiripuranathar, G., et al. (2020). Green and Cost-Effective Synthesis of Metallic Nanoparticles by Algae: Safe Methods for Translational Medicine. Bioengineering (Basel) 7, 129. doi:10. 3390/bioengineering7040129

Verma, S. K., Nisha, K., Panda, P. K., Patel, P., Kumari, P., Mallick, M. A., et al. (2020). Green Synthesized MgO Nanoparticles Infer Biocompatibility by Reducing In Vivo Molecular Nanotoxicity in Embryonic Zebrafish through Arginine Interaction Elicited Apoptosis. Sci. Total Environ. 713, 136521. doi:10. 1016/j.scitotenv.2020.136521

Wei, Y., Salih, K. A. M., Rabie, K., Elwakeel, K. Z., Zayed, Y. E., Hamza, M. F., et al. (2021). Development of Phosphoryl-Functionalized Algal-PEI Beads for the Sorption of Nd(III) and Mo(VI) from Aqueous Solutions - Application for Rare Earth Recovery from Acid Leachates. Chem. Eng. J. 412, 127399. doi:10.1016/j. cej.2020.127399

Wong, C. W., Chan, Y. S., Jeevanandam, J., Pal, K., Bechelany, M., Abd Elkodous, M., et al. (2020). Response Surface Methodology Optimization of MonoDispersed $\mathrm{MgO}$ Nanoparticles Fabricated by Ultrasonic-Assisted Sol-Gel Method for Outstanding Antimicrobial and Antibiofilm Activities. J. Clust Sci. 31, 367-389. doi:10.1007/s10876-019-01651-3

Yao, Y., Gao, B., Chen, J., and Yang, L. (2013). Engineered Biochar Reclaiming Phosphate from Aqueous Solutions: Mechanisms and Potential Application as a Slow-Release Fertilizer. Environ. Sci. Technol. 47, 8700-8708. doi:10.1021/ es4012977

Conflict of Interest: The authors declare that the research was conducted in the absence of any commercial or financial relationships that could be construed as a potential conflict of interest.

Publisher's Note: All claims expressed in this article are solely those of the authors and do not necessarily represent those of their affiliated organizations, or those of the publisher, the editors and the reviewers. Any product that may be evaluated in this article, or claim that may be made by its manufacturer, is not guaranteed or endorsed by the publisher.

Copyright (c) 2022 Fouda, Eid, Abdel-Rahman, EL-Belely, Awad, Hassan, AL-Faifi and Hamza. This is an open-access article distributed under the terms of the Creative Commons Attribution License (CC BY). The use, distribution or reproduction in other forums is permitted, provided the original author(s) and the copyright owner(s) are credited and that the original publication in this journal is cited, in accordance with accepted academic practice. No use, distribution or reproduction is permitted which does not comply with these terms. 